\title{
Environmental isotopes and noble gases in the deep aquifer system of Kazan Trona Ore Field, Ankara, central Turkey and links to paleoclimate
}

\author{
Sebnem Arslan ${ }^{\text {a,b,*, Hasan Yazicigil a, Martin Stute }}{ }^{\text {b,c }}$, Peter Schlosser b,d,e \\ a Department of Geological Engineering, Middle East Technical University, 06800 Ankara, Turkey \\ b Lamont-Doherty Earth Observatory of Columbia University, Palisades, NY 10964, USA \\ c Department of Environmental Science, Barnard College, New York, NY 10027, USA \\ d Department of Earth and Environmental Sciences, Columbia University, New York, NY 10027, USA \\ e Department of Earth and Environmental Engineering, Columbia University, New York, NY 10027, USA
}

\section{A R T I C L E I N F O}

\section{Article history}

Received 20 July 2012

Available online 11 January 2013

\section{Keywords:}

Kazan Basin

Central Turkey

Complex aquifer system

Paleowater

Environmental isotopes

Noble gases

Paleoclimate

\begin{abstract}
A B S T R A C T
Environmental isotopes and noble gases in groundwater samples from the Kazan Trona Ore Field are studied to establish the temperature change between the Holocene and the late Pleistocene. Noble gas temperatures (NGTs) presented in this study add an important facet to the global paleotemperature map in the region between Europe and North Africa. The groundwater system under investigation consists of three different aquifers named shallow, middle and deep in which $\delta^{18} \mathrm{O}$ and $\delta^{2} \mathrm{H}$ vary from $-8.10 \%$ o to $-12.80 \%$ and from $60.89 \%$ to $-92.60 \%$ 。 VSMOW, respectively. The average isotopic depletion between unconfined and confined parts of the system is $-2.5 \%$ in $\delta^{18} \mathrm{O}$ and $-20 \%$ in $\delta^{2} \mathrm{H}$. It is not possible to explain this depletion solely with the elevation effect. Recharge temperatures derived from dissolved atmospheric noble gases reflect the current average yearly ground temperatures $\left(13^{\circ} \mathrm{C}\right)$ for samples collected near the recharge area but are 3 to $8^{\circ} \mathrm{C}$ lower than today's temperatures in the deep aquifer system. Low ${ }^{14} \mathrm{C}$ activities and high He excesses in the confined parts of the aquifer system suggest that the water in the deep aquifer was recharged during the last Pleistocene under considerably cooler climatic conditions.
\end{abstract}

(C) 2012 University of Washington. Published by Elsevier Inc. All rights reserved.

\section{Introduction}

Understanding regional sensitivity to global climate change is crucial for predicting the response to warming caused by humaninduced increases in greenhouse gas concentrations. The reconstruction of past climate variations can help to answer this question (Alley et al., 2003).

The "groundwater noble gas thermometer" is based on the temperature dependence of the solubility of noble gases in water. Noble gas concentrations in groundwater from confined aquifers have been used to reconstruct paleotemperature records primarily for the last glacial period (Mazor, 1972; Andrews and Lee, 1979; Stute and Deak, 1989; Stute et al., 1992, 1995a,1995b; Stute and Schlosser, 1993; Clark et al., 1997; Beyerle et al., 1998; Aeschbach-Hertig et al., 2002; Hall et al., 2005; Castro et al., 2007; Klump et al., 2008; Blaser et al., 2010; Alvarado et al., 2011; Varsanyi et al., 2011). These studies have

\footnotetext{
* Corresponding author at: Department of Geological Engineering, Ankara University, 06100 Ankara, Turkey. Fax: +90 3122150487

E-mail address: sebnem_okten@yahoo.com (S. Arslan).
}

shown that selected confined aquifers can be considered as low-pass filtered continental paleoclimate archives. The length of the records is limited by the available dating methods (primarily radiocarbon), as well as diffusion and dispersion within the archive.

A confined aquifer system near Ankara, Turkey was studied in the context of exploitation of a trona deposit. Trona $\left(\mathrm{Na}_{2} \mathrm{CO}_{3} \cdot \mathrm{NaHCO}_{3} \cdot 2 \mathrm{H}_{2} \mathrm{O}\right)$ is a rare, naturally occurring mineral refined to soda ash used mainly in glass manufacturing. Kazan trona is found in the Eocene deposits of the Kazan Basin and will be extracted by using solution mining technology. After the discovery of the deposit, groundwater resources in the area were characterized hydrogeologically and hydrogeochemically to assess the potential impacts of solution mining on the aquifer system (Yazicigil et al., 2001, 2009; SRK, 2004; Camur et al., 2008). To provide supporting evidence for the mixing mechanisms within the complex hydrogeologic system, consisting of three different aquifers above the deposit, a multi-tracer approach was utilized $\left(\delta^{18} \mathrm{O}, \delta^{2} \mathrm{H}, \delta^{13} \mathrm{C}\right.$ and ${ }^{14} \mathrm{C}$ of DIC, ${ }^{3} \mathrm{H}, \mathrm{CFC}-11$ and CFC-12, He and $\mathrm{Ne}$ ) and groundwater residence times were established (Arslan, 2008; Arslan et al., 2012). Arslan et al. (2012) used the residence times to derive information needed for the development of strategies for sustainable groundwater management throughout the area, since significant amounts of water from local aquifers would be required during solution 
mining extraction of the trona deposit. Additionally, presence of mantle-derived helium in some shallow aquifer samples were attributed to the transport of helium along deep buried faults in the basin (Arslan et al., 2012).

In this study, the environmental isotopes of hydrogen, oxygen and carbon $\left(\mathrm{D},{ }^{18} \mathrm{O},{ }^{3} \mathrm{H},{ }^{13} \mathrm{C},{ }^{14} \mathrm{C}\right)$, as well as noble gas thermometry were used to infer information on climate change between the Holocene and the Pleistocene epochs around Ankara, central Turkey.

\section{Description of the study area}

\section{Morphology and climate background}

The study area is located on the flanks of the Kazan Basin, $35 \mathrm{~km}$ northwest of Ankara, Turkey (Fig. 1). Kazan Basin is an elongated NESW trending depression surrounded by the Kizilcahamam and Zir volcanic terrains to the north and south and by the Orhaniye and Kinik uplifts to the east and west. The elevation in the area changes from 850 to $1410 \mathrm{~m}$ asl. The area has a continental semi-arid climate and the summers are warm and dry and winters are moist and cold. The average annual mean temperature, precipitation, potential evaporation and relative humidity at an elevation of $891 \mathrm{~m}$ are $11.9^{\circ} \mathrm{C}$, $389.1 \mathrm{~mm}, 1112.2 \mathrm{~mm}$, and 60.5\%, respectively, as recorded at Ankara
Station between 1930 and 2006 (Turkish State Meteorological Service, personal communication).

Unfortunately, there is no information on late Pleistocene paleoclimate in the study area. There are a number of studies quantifying climatic changes in central Turkey (Eski Acigol, Konya Basin and Mount Erciyes) during the Late Pleistocene based on sediment records (Kuzucuoglu et al., 1999; Roberts et al., 2001), lake isotope paleohydrology (Jones et al., 2007) and glacial modeling (Sarikaya et al., 2009). Kuzucuoglu et al. (1999) reconstructed the environmental changes in central Anatolia during the last 150 ka in Konya Basin, stating that between 150 and 170 ka the climate was cold and dry and vegetation was steppe-like and treeless. Between 115 and 66 ka there were periods of increasing aridity, and from 66 to 30 ka climate was slightly warmer than the previous period. The pleniglacial period (2418 cal ka BP) was extremely dry and there was a severe drought during the late glacial period (18-12 cal ka BP). Sarikaya et al. (2009) used ${ }^{36} \mathrm{Cl}$ dating and glacier modeling in Mount Erciyes to reveal the paleoclimate in central Turkey during the last $22 \mathrm{ka}$ and stated that the LGM climate (21.3 ka) was 8 to $11^{\circ} \mathrm{C}$ colder than today and moisture levels were similar to modern values. Emeis et al. (2000) derived a $9^{\circ} \mathrm{C}$ drop in sea-surface temperatures for the Ionian sea relative to present day for the glacial period $(19 \mathrm{ka})$. It has also been proposed that temperature changes in the eastern Mediterranean are similar on land and at sea (Bar-Matthews et al., 2003).
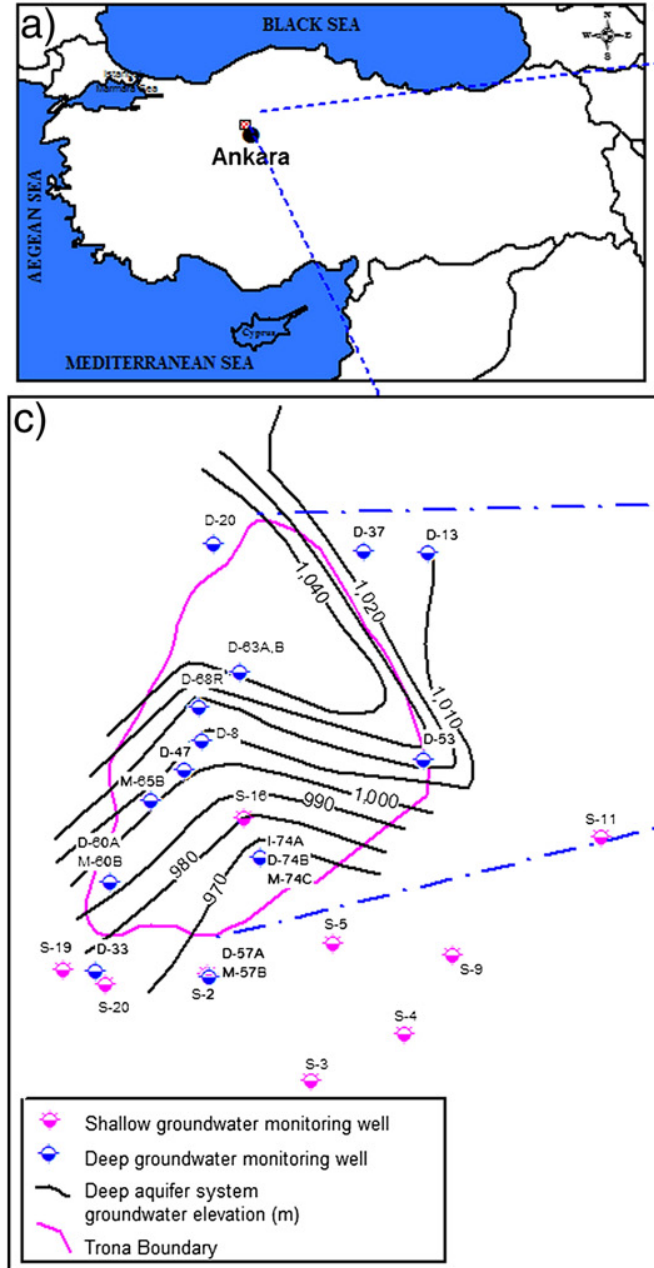

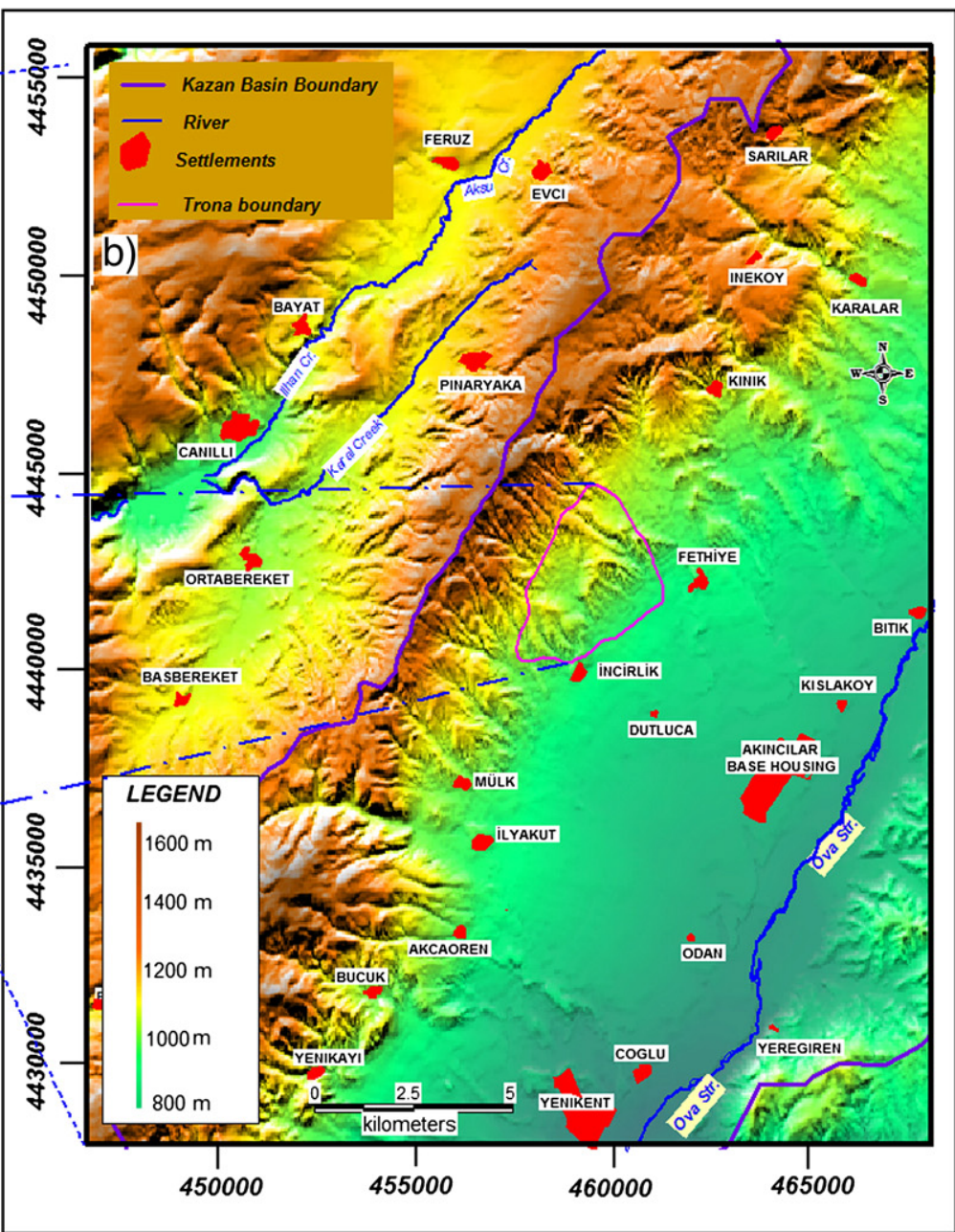

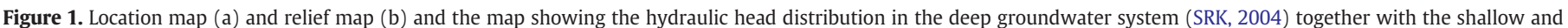
deep groundwater monitoring well locations (c). Universal Transverse Mercator (UTM) coordinate system is used in relief map margins. Datum: ED50, Zone 36. 


\section{Geological background}

The geological information given here is a compilation of previous investigations carried out by Toprak and Rojay (2000), Toprak and Rojay (2001) and Rojay et al. (2002). According to these studies, the basement rocks in the area are formed from a Paleozoic NE-SW trending metamorphic belt in the northwest of the area and Paleogene volcanic rocks in the southwest. They consist of black, intensely deformed graphitic schists that enclose gray, thick-bedded, dismembered, and intensely fractured limestones. The basement rocks are overlain by the Eocene deposits, which are developed as a transgressive sequence from a lacustrine to a shallow-marine depositional setting. These units crop out as a NE-SW trending belt in the area (Fig. 2). The lower sequence of the Eocene Mulk Formation consists of intensely deformed brownish yellow mudstones, siltstones and sandstones with green volcanic inclusions and hosts the trona deposit. The upper sequence (Akpinar Formation) is made up of cross-laminated siltstones, sandstones and conglomerates followed by fossiliferous sandy limestones. The Akpinar Formation is followed by the Neogene units, which consist of deformed clayey and fractured limestones at the bottom and a porous sandstone-conglomerate sequence towards the top. Neogene units are unconformably overlain by the Pliocene units composed of highly porous, well-rounded, poorly cemented, compacted and sorted conglomerates and siltstone-mudstone-sandstone alternations. Quaternary deposits in the area are characterized by the colluvium/talus accumulations, alluvium, alluvial fans and slope deposits and consist of angular to subrounded pebbles in the hills and loose pebbles and silts in the flat-lying surfaces (Fig. 2).

\section{Hydrogeological background}

The groundwater system in the area consists of three different aquifers: shallow, intermediate and deep (Fig. 3) (SRK, 2004). The shallow aquifer system is present in the Quaternary deposits under unconfined conditions. The middle groundwater system is present in the fractures developed as a result of faulting and in the basal conglomerates of the Neogene unit. The system is uncovered in the middle of the study area between Incirlik and Fethiye villages (Fig. 2), whereas to the east it is completely covered by Quaternary units (Fig. 3). A thick aquitard consisting of the Akpinar Formation separates this system from the underlying deep aquifer in the north of Incirlik village. Toward the south of the village, the middle system lies directly above the deep system. The average thickness of this aquifer is estimated to be $50 \mathrm{~m}$ (SRK, 2001). The deep confined groundwater system is present in the extensively fractured sections of the Eocene Mulk Formation. The thickness of the deep aquifer is more than $400 \mathrm{~m}$ in the west of the trona deposit and it decreases toward the east to about $100 \mathrm{~m}$ (SRK, 2004). The system is confined except for the outcrop area where it is recharged. The Eocene formations outcrop around elevations of $1150-1400 \mathrm{~m}$. There is a groundwater mound at the northern end of the trona deposit and the groundwater flow is to the northeast and southeast from this mound (Fig. 1). The hydraulic conductivity ranges from $2 \times 10^{-10} \mathrm{~m} \mathrm{~s}^{-1}$ in the matrix rock to $3 \times 10^{-4} \mathrm{~m} \mathrm{~s}^{-1}$ in the most fractured sections (SRK, 2004). There is an upward vertical gradient between the deep system and overlying units increasing in magnitude in the direction of flow. At the southern half of the trona deposit area, the presence of a
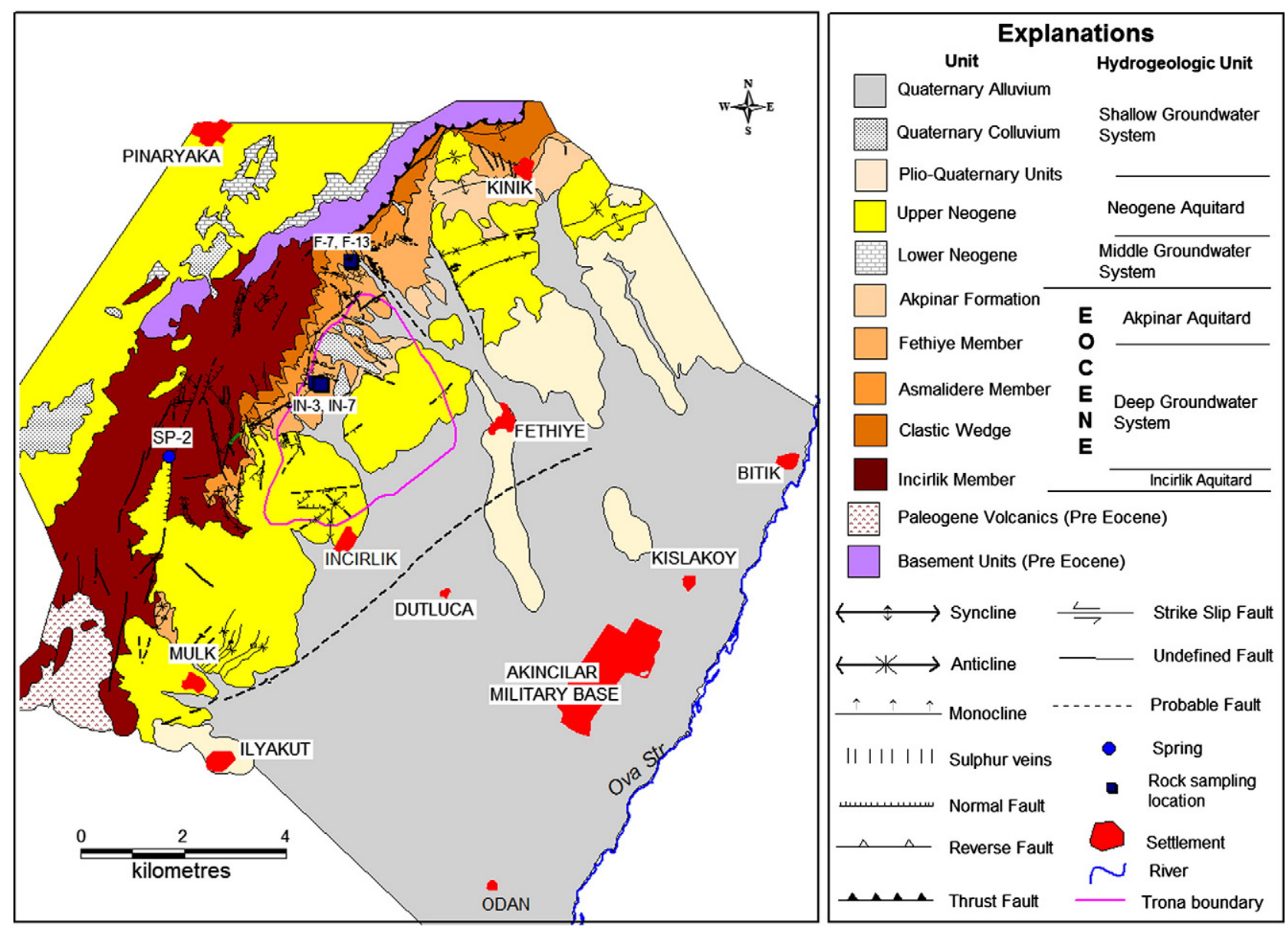

Figure 2. Geological map of the study area. Modified from Toprak and Rojay (2001). 


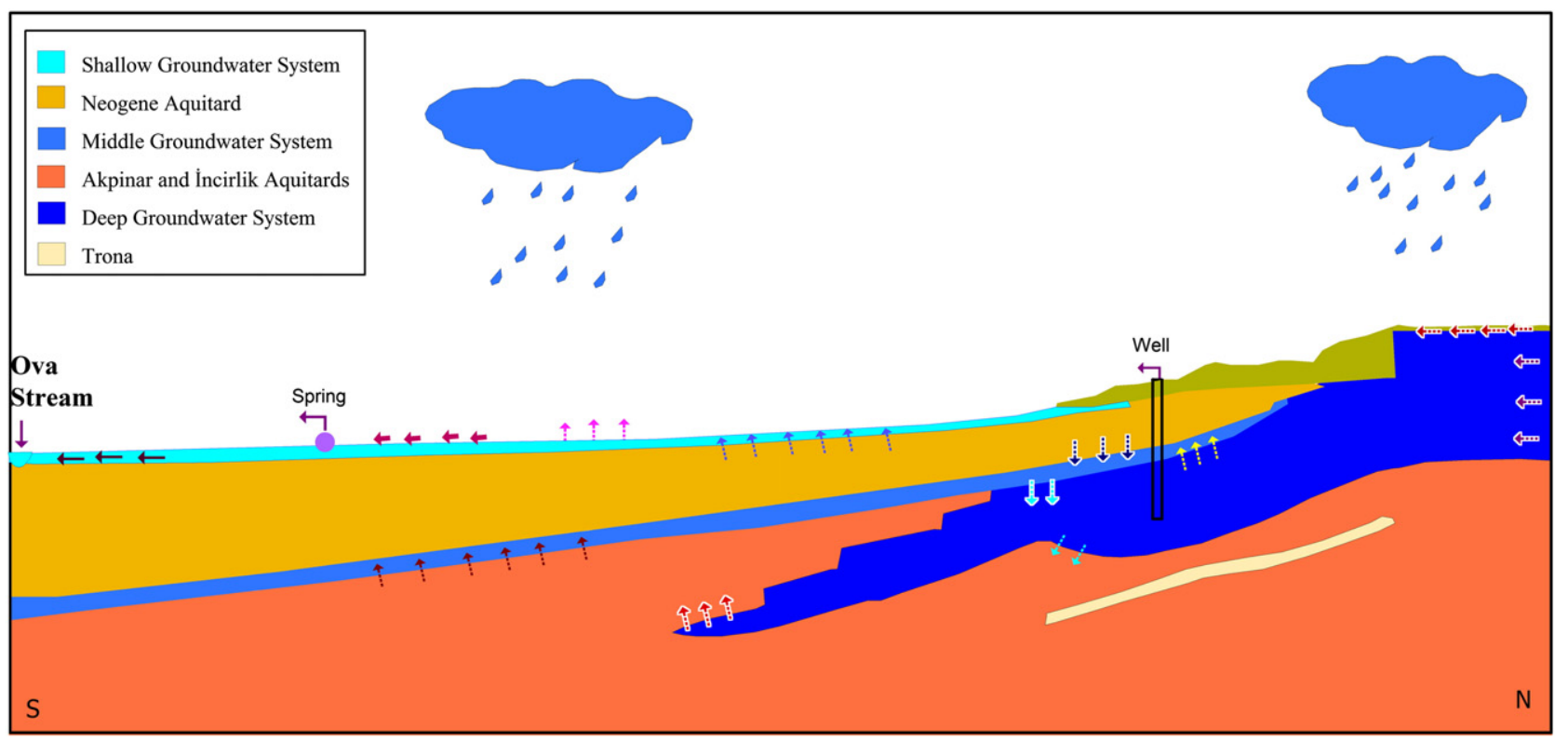

Figure 3. Cross-section showing the shallow, middle and deep groundwater systems (arrows indicate the groundwater flow directions). Modified from Yazicigil et al. (2009).

saline zone in the fractured rock system affects the groundwater quality in this system (SRK, 2001).

\section{Methods}

Field sampling

Three field trips were carried out between the summers of 2006 and 2007 in the Kazan Basin. A total of 28 representative samples were collected from the groundwater wells monitoring different depths ranging from $4 \mathrm{~m}$ to $540 \mathrm{~m}$ below ground surface. In situ $\mathrm{pH}$, temperature, electrical conductivity and dissolved oxygen measurements were carried out and the samples were collected after the field parameters reached equilibrium to ensure that they represent the water in the aquifer. $60-\mathrm{ml}$ Boston round clear glass bottles with $20-\mathrm{mm}$ sized poly seal screw caps were used to collect samples for stable isotope analysis, $250 \mathrm{ml}$ Boston round clear glass bottles with $24 \mathrm{~mm}$ screw caps were used to collect samples for ${ }^{3} \mathrm{H}$, ${ }^{13} \mathrm{C}$ and ${ }^{14} \mathrm{C}$ analysis. $0.2 \mathrm{ml}$ of saturated $\mathrm{HgCl}_{2}$ solution was added to ${ }^{13} \mathrm{C}$ and ${ }^{14} \mathrm{C}$ samples immediately after collection to prevent post-collection biological activity from changing the carbon isotopic composition. During noble gas sampling, $50 \mathrm{~cm}$ long, $1-\mathrm{cm}$ outer diameter copper tubes fixed in aluminum channels were sealed on both ends by stainless steel pinch-off clamps (Weiss, 1968). The formation of gas bubbles was reduced by attaching a back-pressure valve assembly; the details of the procedure are explained in Stute et al. (1995a).

Another field trip was carried out in May 2010 to collect samples from the geological units hosting the deep aquifer system (Eocene Mulk Formation) and a total of 13 samples were collected and analyzed for $U$ and Th concentrations. The sampling locations are presented in Figure 2.

\section{Laboratory analysis}

Stable isotope ratios $\delta^{18} \mathrm{O}$ and $\delta \mathrm{D}$ were measured in the Environmental Isotope Laboratory of University of Waterloo (Drimmie and Heemskerk, 2001; Drimmie et al., 2001), Canada, by using a Micromass ISOPRIME Continuous Flow Isotope Ratio Mass spectrometer (CFIRMS). Analytical uncertainties of the individual measurements are estimated to be within $\pm 0.2 \%$ ofor $\delta^{18} \mathrm{O}$ and $\pm 0.8 \%$ 。 for $\delta \mathrm{D}$.
Tritium concentrations were determined by the ${ }^{3} \mathrm{He}$-ingrowth method (Clarke et al., 1976). The samples were degassed and flame-sealed in glass bulbs where they were stored for more than 4 months. After storage, the ${ }^{3} \mathrm{He}$ which had accumulated from tritium decay was extracted and admitted to a VG-5400 He isotope mass spectrometer at Lamont-Doherty Earth Observatory (Ludin et al., 1997). The analytical precision and the detection limit of the tritium measurements was about $\pm 0.1 \mathrm{TU}$ (tritium units, $1 \mathrm{TU}$ is equivalent to a ${ }^{3} \mathrm{H} /{ }^{1} \mathrm{H}$ ratio of $10^{-18}$ ).

${ }^{13} \mathrm{C} /{ }^{12} \mathrm{C}$ and ${ }^{14} \mathrm{C} /{ }^{12} \mathrm{C}$ ratios were measured at the National Ocean Sciences Accelerator Mass Spectrometry Facility (NOSAMS) of Woods Hole Oceanographic Institution by converting Dissolved Inorganic Carbon (DIC) to $\mathrm{CO}_{2} \cdot{ }^{13} \mathrm{C} /{ }^{12} \mathrm{C}$ analyses were carried out by using a VG PRISM Stable Mass Spectrometer with a precision of $\pm 0.05 \%$. ${ }^{14} \mathrm{C} /{ }^{12} \mathrm{C}$ analyses were performed by using an accelerator mass spectrometry (AMS) system following the procedures described in WHOI (1989). The results are given as percent modern carbon ( $\mathrm{pmc}$ ) and the analytical precision and detection limits are reported to be within $\pm 1 \%$ and $0.07 \mathrm{pmc}$, respectively.

The dissolved gases were extracted from the copper tubes on a vacuum line and the individual noble gases were separated and analyzed by using a multi-purpose noble gas mass spectrometer (MAP 215-50) at L-DEO. The procedure has been described in detail by Stute et al. (1995a). The precision of the measurements is about \pm 1 to $2 \%$ for noble gas abundances and helium isotope ratios.

Concentrations of total $U$ and Th in aquifer material samples were measured at Brooklyn College (City University of New York) with inductively coupled plasma mass spectrometry (ICP-MS). The samples were prepared as follows: $0.05 \mathrm{~g}$ of powdered rock sample was placed in Teflon vessel and dissolved in $3 \mathrm{ml} \mathrm{HF}+1 \mathrm{ml}$ $\mathrm{HNO}_{3}+1 \mathrm{ml} \mathrm{H}_{2} \mathrm{O}$ solution for 2 days on a hot plate $\left(180^{\circ} \mathrm{C}\right)$. The solution was then completely evaporated and $2.5 \mathrm{ml} \mathrm{HNO}_{3}$ and $2.5 \mathrm{ml} \mathrm{DI}$ water were added. This new solution was left on the hot plate at $100^{\circ} \mathrm{C}$ for 2 days. This process was repeated and $0.5 \mathrm{ml}$ of the final solution was added to $9.5 \mathrm{ml}$ DI water followed by measurement in ICP-MS.

\section{Results}

Results of the chemical data collected in the field, isotopic analyses and noble gas isotope measurements are reported in Tables 1,2 and 3, 
respectively. Electrical conductivity (EC) values range from 526 to $23,902 \mu \mathrm{Scm}^{-1}$, the highest values observed in both shallow and deep systems (Table 1). pH values vary between 7.53 and 12.29 , with the highest values found in the middle aquifer system. Dissolved oxygen contents of the samples from the shallow system range from 0.1 to $10 \mathrm{mg} \mathrm{l}^{-1}$, and for the deeper systems it is $<0.05 \mathrm{mg} \mathrm{l}^{-1}$ (Table 1).

Stable isotope ratios of the water molecule within the aquifer systems cover a wide range of values from $-8.10 \%$ o to $-12.80 \%$ 。 and from $-60.89 \%$ o to $-92.60 \%$ V-SMOW for $\delta^{18} \mathrm{O}$ and $\delta \mathrm{D}$, respectively. Isotopically lighter values are found in the deep aquifer system (Table 2). An isotopic contrast is observed between the shallow and deep aquifer systems (Fig. 4). Most of the $\delta^{18} \mathrm{O}$ and $\delta \mathrm{D}$ samples from the deep aquifer system fall along the global meteoric water line (GMWL) whereas most samples from the shallow unconfined aquifer and a few of the confined aquifer plot to the right of the meteoric water line (Fig. 4).

$\delta^{13} \mathrm{C}$ values for DIC show an enrichment from shallow to deeper aquifers and range from $-8.65 \%$ near the recharge area to values up to $+3.52 \%$ in the deep aquifer system (e.g., samples D-57A, D-47 and $\mathrm{D}-8$; Table 2). ${ }^{14} \mathrm{C}$ activities are close to the detection limits $(0.07 \mathrm{pmc})$ for some of the samples from the deep system (e.g., samples D-57A, D-47; Table 2).

The concentrations of noble gases were measured in a total of 15 samples, 8 of which are from the shallow system and the rest from the deep, confined aquifer system (Table 3 ). Helium concentrations vary between $5 \times 10^{-8}$ and $1.5 \times 10^{-5} \mathrm{~cm}^{3} \mathrm{STP} \mathrm{g}{ }^{-1} .{ }^{3} \mathrm{He} /{ }^{4} \mathrm{He}$ ratios range between $0.13 \times 10^{-6}$ and $1.71 \times 10^{-6}$. The highest ${ }^{3} \mathrm{He} /{ }^{4} \mathrm{He}$ ratios were found in water from the shallow aquifer, the lowest in the deep aquifer (Table 3 ).

Results of the $U$ and Th concentrations in aquifer rocks are presented in Table 4 . $U$ and Th concentrations range from $0.85 \mathrm{ppm}$ to $2.54 \mathrm{ppm}$ and from $2.02 \mathrm{ppm}$ to $5.20 \mathrm{ppm}$, respectively.

\section{Calculation of noble gas temperatures}

The interpretation of noble gases in groundwater requires correction of the "excess air" component (Heaton and Vogel, 1981). There are three models proposed to explain the formation of excess air, which are total dissolution (TD) of trapped bubbles (Andrews and Lee, 1979; Stute and Schlosser, 1993), partial re-equilibration (PR) with the atmosphere after total dissolution (Stute et al., 1995b), and closed-system equilibration (CE) of groundwater with partially dissolved entrapped air which are discussed in detail in AeschbachHertig et al. (2000). In this study, these models were fitted by the inverse algorithm of Aeschbach-Hertig et al. (1999) to the noble gas data of 15 samples obtained from the aquifers above the Kazan Trona ore field. Here, only the CE model equation presented by AeschbachHertig et al. (2000) is given (Eq. (1)).

$C_{i}(T, S, P, A, F)=C_{i}^{*}(T, S, P)+\frac{(1-F) A z_{i}}{1+F A z_{i} / C_{i}^{*}}(\mathrm{i}=\mathrm{He}, \mathrm{Ne}, \mathrm{Ar}, \mathrm{Kr}, \mathrm{Xe})$

where $C_{i}^{*}(T, S, P)$ defined as the moist air solubility equilibrium concentrations as functions of temperature, salinity $\left(\mathrm{g} \mathrm{kg}^{-1}\right)$ and atmospheric pressure (atm) (Weiss, 1970, 1971; Weiss and Kyser, 1978; Clever, 1979), $z_{i}$ are the noble gas volume fractions in dry air. $F$ shows the fractionation of excess air and $A$ denotes the initial amount of dry entrapped air per unit mass of water.

Equation (1) is not applicable to the observed He for the aquifer system in this study due to the presence of non-atmospheric He. The parameter $S$ can be estimated as: $S=0 \%$ for the meteoric recharge water although in two of the samples (S-4 and D-47) EC values are up to $14,069 \mu \mathrm{s} \mathrm{cm}^{-1}$ corresponding to a salinity value of $\sim 10 \mathrm{~g} \mathrm{~kg}^{-1}$. A salinity correction should be carried out for these two samples, assuming that during the measurements there is salt in the samples

Table 1

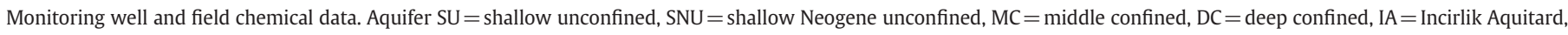
N.D. $=$ not determined.

\begin{tabular}{|c|c|c|c|c|c|c|c|c|c|}
\hline \multirow[t]{2}{*}{ Sample } & \multicolumn{2}{|c|}{$\begin{array}{l}\text { Depth to screened zone } \\
\text { [m] }\end{array}$} & \multirow[t]{2}{*}{ Aquifer } & \multicolumn{2}{|c|}{ Coordinates } & \multirow[t]{2}{*}{ Cond. $[\mu \mathrm{s} / \mathrm{cm}]$} & \multirow[t]{2}{*}{ Temp. $\left[\mathrm{C}^{\circ}\right]$} & \multirow[t]{2}{*}{$\mathrm{pH}$} & \multirow[t]{2}{*}{$\mathrm{DO}[\mathrm{mg} / \mathrm{l}]$} \\
\hline & Top & Bottom & & Northing & Easting & & & & \\
\hline S-2 & 8 & 20 & SU & 458866.8 & 4439755.7 & 742 & 13.4 & 7.94 & 2.0 \\
\hline$S-3$ & 8 & 20 & SU & 459986.4 & 4438608.1 & 726 & 14.3 & 7.53 & 3.0 \\
\hline S-4 & 5 & 9 & SU & 461000.0 & 4439113.0 & 14069 & 15.2 & 7.64 & 0.7 \\
\hline S-5 & 8 & 20 & SU & 460231.6 & 4440080.6 & 625 & 13.9 & 7.96 & 10.0 \\
\hline S-9 & 7 & 15 & SU & 461520.5 & 4439964.2 & 2673 & 13.6 & 8.32 & 0.1 \\
\hline S-11 & 4 & 12 & SU & 463142.2 & 4441246.7 & 816 & 14.6 & 7.71 & 0.4 \\
\hline S-16 & 7 & 23 & SU & 459264.3 & 4441443.7 & 725 & 11.1 & 7.62 & 5.5 \\
\hline S-19 & 4 & 20 & SNU & 457306.5 & 4439795.9 & 610 & 13.3 & 7.90 & 5.0 \\
\hline S-20 & 4 & 20 & SNU & 457763.0 & 4439650.9 & 526 & 12.1 & 7.75 & 5.0 \\
\hline$S-22 A$ & 13 & 21 & SNU & 457680.0 & 4439963.3 & 684 & 12.8 & 7.67 & 5.0 \\
\hline D-8 & 158.99 & 188.74 & DC & 458803.4 & 4442308.8 & 3130 & 18.4 & 9.61 & 0.0 \\
\hline D-13 & 361.79 & 391.54 & DC & 461261.3 & 4444346.2 & 920 & 13.5 & 8.91 & 0.0 \\
\hline D-20 & 191.96 & 221.71 & DC & 458931.9 & 4444438.2 & 879 & 15.0 & 7.57 & N.D. \\
\hline D-33 & 151.43 & 163.33 & DC & 457656.3 & 4439808.0 & 1759 & 15.7 & 8.74 & 0.0 \\
\hline D-37 & 211.78 & 241.53 & DC & 460556.8 & 4444364.9 & 880 & 16.9 & 8.96 & 0.0 \\
\hline D-47 & 72 & 372 & DC & 458608.2 & 4441977.3 & 5486 & 17.2 & 9.24 & 0.05 \\
\hline D-53 & 546 & 576 & DC & 461207.0 & 4442103.7 & 6354 & 12.3 & 9.20 & N.D \\
\hline D-57A & 300.71 & 318.62 & $\mathrm{DC}$ & 458876.9 & 4439740.0 & 6707 & 17.2 & 8.01 & 0.0 \\
\hline M-57B & 132.09 & 144.03 & MC & 458875.4 & 4439742.4 & 2360 & 12.8 & 8.81 & 0.0 \\
\hline D-60A & 280 & 292 & $\mathrm{DC}$ & 457814.6 & 4440764.3 & 525 & 13.0 & 8.77 & N.D. \\
\hline M-60B & 114 & 126 & MC & 457814.6 & 4440764.3 & 573 & 12.7 & 9.34 & 0.0 \\
\hline D-63A & 199 & 211 & $\mathrm{DC}$ & 459207.3 & 4443039.4 & 606 & 18.1 & 7.91 & 0.0 \\
\hline D-63B & 110.5 & 122.5 & $\mathrm{DC}$ & 459207.3 & 4443039.4 & 641 & 14.0 & 8.87 & 0.0 \\
\hline M-65B & 101 & 117 & MC & 458254.2 & 4441658.1 & 4175 & 13.9 & 12.24 & N.D. \\
\hline D-68R & 63 & 83 & $\mathrm{DC}$ & 458768.0 & 4442660.0 & 739 & 15.7 & 8.53 & 0.0 \\
\hline I-74A & 520 & 544 & IA & 459431.0 & 4441041.0 & 6919 & 10.7 & 8.06 & N.D. \\
\hline D-74B & 282 & 294 & $\mathrm{DC}$ & 459431.0 & 4441041.0 & 23902 & 7.8 & 8.41 & N.D. \\
\hline $\mathrm{M}-74 \mathrm{C}$ & 78 & 96 & MC & 459431.0 & 4441041.0 & 6455 & 12.4 & 12.29 & N.D. \\
\hline
\end{tabular}


Table 2

Isotopic composition of groundwater from the Kazan Trona aquifers. N.D. = not determined.

\begin{tabular}{|c|c|c|c|c|c|c|c|c|c|c|c|}
\hline Sample & $\begin{array}{l}\delta^{18} \mathrm{O} \text { VSMOW } \\
{[\% \circ]}\end{array}$ & $\begin{array}{l}\delta^{2} \mathrm{H} \text { VSMOW } \\
{[\% \circ]}\end{array}$ & $\begin{array}{l}\text { Rech. elev. } \\
(\mathrm{m})\end{array}$ & $\begin{array}{l}{ }^{3} \mathrm{H} \\
\mathrm{TU}\end{array}$ & $\mathrm{DIC}[\mathrm{mmol} / \mathrm{l}]$ & $\begin{array}{l}\delta^{13} \mathrm{C} \text { VPDB } \\
{[\% \circ]}\end{array}$ & $\begin{array}{l}\mathrm{A}^{14} \mathrm{C} \\
{[\mathrm{pmc}]}\end{array}$ & $\begin{array}{l}\text { Alkalinity } \\
{[\mathrm{mg} / \mathrm{l}]}\end{array}$ & $\begin{array}{l}\mathrm{a}_{0}^{14} \mathrm{C}_{\text {DIC }} \\
{[\mathrm{pmc}]}\end{array}$ & $\mathrm{q}$ & $\begin{array}{l}\text { Corrected age } \\
\left({ }^{14} \mathrm{C} \text { ka BP }\right)\end{array}$ \\
\hline S-2 & -9.39 & -69.21 & 1050 & 2.47 & N.D. & N.D. & N.D. & 366 & N.D. & N.D. & N.D. \\
\hline S-3 & -9.56 & -68.61 & 1050 & 6.05 & N.D. & N.D. & N.D. & 431 & N.D. & N.D. & N.D. \\
\hline S-4 & -8.1 & -64.57 & 1050 & 0.13 & 9.07 & -8.65 & 29.79 & 499 & 68 & 0.41 & -0.6 \\
\hline$S-5$ & -9.67 & -68.55 & 1050 & 6.96 & N.D. & N.D. & N.D. & 392 & N.D. & N.D. & N.D. \\
\hline S-9 & -10.04 & -73.88 & 1050 & 0.02 & 16.39 & -8.17 & 24.00 & 747 & 68 & 0.39 & 0.9 \\
\hline S-11 & -9.86 & -69.13 & 1050 & N.D. & N.D. & N.D. & N.D. & 388 & N.D. & N.D. & N.D. \\
\hline S-16 & -9.88 & -69.42 & 1050 & 6.58 & N.D. & N.D. & N.D. & 416 & N.D. & N.D. & N.D. \\
\hline S-19 & -8.1 & -60.89 & 1050 & 14.22 & N.D. & N.D. & N.D. & 464 & N.D. & N.D. & N.D. \\
\hline S-20 & -9.3 & -67.91 & 1050 & 4.96 & N.D. & N.D. & N.D. & 374 & N.D. & N.D. & N.D. \\
\hline$S-22 A$ & -8.86 & -65.51 & 1050 & 4.44 & N.D. & N.D. & N.D. & 463 & N.D. & N.D. & N.D. \\
\hline D-8 & -12.31 & -88.60 & 1250 & 0.05 & 12.79 & 2.28 & 0.17 & 2163 & 68 & 0.06 & 25.8 \\
\hline D-13 & -12.30 & -90.07 & 1250 & 0.11 & 12.51 & -2.30 & 0.45 & 674 & 68 & 0.20 & 28.3 \\
\hline D-20 & -10.60 & -74.70 & 1250 & 0.32 & 8.06 & -7.01 & 27.81 & 409 & 68 & 0.36 & -1.2 \\
\hline D-33 & -12.90 & -90.80 & 1250 & N.D. & N.D. & N.D. & N.D. & 2702 & N.D. & N.D. & N.D. \\
\hline D-37 & -12.37 & -89.60 & 1250 & 0.07 & 12.01 & -3.00 & 0.29 & 622 & 68 & 0.23 & 32.8 \\
\hline D-47 & -12.50 & -92.12 & 1250 & N.D. & 69.50 & 2.76 & 0.15 & N.D. & 68 & 0.04 & 23.8 \\
\hline D-53 & -8.59 & -68.20 & 1250 & N.D. & N.D. & N.D. & N.D. & 5639 & N.D. & N.D. & N.D. \\
\hline D-57A & -12.80 & -90.30 & 1250 & 0.00 & 95.72 & 3.52 & 0.08 & 5406 & 68 & 0.02 & 21.9 \\
\hline M-57B & -12.70 & -92.60 & 1250 & N.D. & N.D. & N.D. & N.D. & 2542 & N.D. & N.D. & N.D. \\
\hline D-60A & -12.50 & -90.99 & 1250 & 0.07 & N.D. & N.D. & N.D. & 398 & N.D. & N.D. & N.D. \\
\hline M-60B & -12.54 & -90.60 & 1250 & 0.09 & 7.07 & -6.64 & 0.39 & 485 & 68 & 0.34 & 33.9 \\
\hline D-63A & -11.00 & -78.70 & 1250 & 0.05 & 7.80 & -7.74 & 3.70 & 386 & 68 & 0.38 & 16.0 \\
\hline D-63B & -11.40 & -82.23 & 1250 & N.D. & N.D. & N.D. & N.D. & 453 & N.D. & N.D. & N.D. \\
\hline M-65B & -9.72 & -72.90 & 1250 & N.D. & N.D. & N.D. & N.D. & 2324 & N.D. & N.D. & N.D. \\
\hline D-68R & -12.25 & -89.00 & 1250 & 0.04 & 7.71 & -6.33 & 0.80 & 391 & 68 & 0.33 & 27.7 \\
\hline I-74A & -11.90 & -90.10 & 1250 & N.D. & N.D. & N.D. & N.D. & N.D. & N.D. & N.D. & N.D. \\
\hline D-74B & -8.65 & -67.80 & 1250 & N.D. & N.D. & N.D. & N.D. & 991 & N.D. & N.D. & N.D. \\
\hline M-74C & -10.00 & -76.90 & 1250 & N.D. & N.D. & N.D. & N.D. & 2408 & N.D. & N.D. & N.D. \\
\hline
\end{tabular}

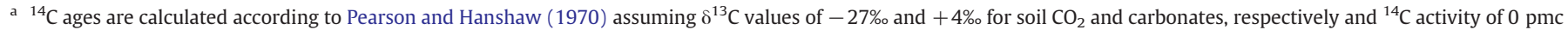
for carbonates.

besides water. Nevertheless, the salinity is ignored due to the fact that this correction would only change the temperatures by less than $0.27^{\circ} \mathrm{C}$.

In Eq. (1), the parameter P depends on the recharge elevations. For the samples from the deep system the recharge elevations vary between $1150 \mathrm{~m}$ and $1400 \mathrm{~m}$ where Eocene units outcrop corresponding to $\mathrm{P}$ values between $0.871 \mathrm{~atm}$ and $0.845 \mathrm{~atm}$, respectively. For the shallow aquifer, recharge elevations change between 1050 and $900 \mathrm{~m}$ where alluvium units outcrop corresponding to $\mathrm{P}$ values between $0.882 \mathrm{~atm}$ and $0.898 \mathrm{~atm}$. The sensitivity of the NGTs to elevation is small, a change in assumed elevation of the recharge area from 1150 to $1400 \mathrm{~m}(250 \mathrm{~m})$ results in a $0.7^{\circ} \mathrm{C}$ lower recharge temperature equivalent to an altitude effect of $0.3^{\circ} \mathrm{C} / 100 \mathrm{~m}$. Therefore, the

Table 3

Noble gas data.

\begin{tabular}{|c|c|c|c|c|c|c|}
\hline \multirow[t]{2}{*}{ Sample } & $\mathrm{He}$ & $\mathrm{Ne}$ & $\mathrm{Ar}$ & $\mathrm{Kr}$ & $\mathrm{Xe}$ & ${ }^{3} \mathrm{He} /{ }^{4} \mathrm{He}$ \\
\hline & $\begin{array}{l}10^{-8} \mathrm{~cm}^{3} \\
\text { STP g }\end{array}$ & $\begin{array}{l}10^{-7} \mathrm{~cm}^{3} \\
\text { STP g }\end{array}$ & $\begin{array}{l}10^{-4} \mathrm{~cm}^{3} \\
\text { STP } \mathrm{g}^{-1}\end{array}$ & $\begin{array}{l}10^{-8} \mathrm{~cm}^{3} \\
\text { STP }\end{array}$ & $\begin{array}{l}10^{-8} \mathrm{~cm}^{3} \\
\text { STP }\end{array}$ & $10^{-6}$ \\
\hline S-2 & 5.042 & 2.008 & 3.540 & 7.948 & 1.133 & 1.71 \\
\hline S-3 & 1204.265 & 2.128 & 3.411 & 7.815 & 1.109 & 0.28 \\
\hline S-4 & 22.216 & 2.034 & 3.264 & 7.275 & 1.020 & 0.43 \\
\hline S-5 & 4.586 & 1.992 & 3.269 & 7.504 & 1.007 & 1.39 \\
\hline S-9 & 754.540 & 2.289 & 3.681 & 8.405 & 1.182 & 0.22 \\
\hline S-11 & 131.669 & 2.408 & 3.637 & 8.007 & 1.108 & 1.15 \\
\hline S-16 & 5.082 & 2.078 & 3.678 & 8.067 & 1.117 & 1.43 \\
\hline S-19 & 5.391 & 2.182 & 3.337 & 7.872 & 1.050 & 1.78 \\
\hline D-8 & 31.906 & 3.058 & 4.635 & 10.019 & 1.409 & 0.40 \\
\hline D-13 & 37.983 & 2.853 & 4.342 & 9.716 & 1.401 & 0.32 \\
\hline D-33 & 86.419 & 2.668 & 4.208 & 9.224 & 1.280 & 0.13 \\
\hline D-37 & 33.305 & 2.815 & 4.340 & 9.767 & 1.410 & 0.34 \\
\hline D-47 & 1531.444 & 2.843 & 4.254 & 9.589 & 1.284 & 0.20 \\
\hline D-63A & 11.247 & 3.018 & 4.313 & 9.532 & 1.473 & 0.90 \\
\hline D-68R & 12.136 & 3.044 & 4.548 & 10.119 & 1.517 & 0.76 \\
\hline
\end{tabular}

recharge elevations are assumed to be the average elevations where units outcrop and the calculations were carried out based on these average elevations (1050 $\mathrm{m}$ for the shallow system, $1250 \mathrm{~m}$ for the deep system).

Equation (1) was solved for the unknown parameters by inverse modeling using four measured concentrations ( $\mathrm{Ne}, \mathrm{Ar}, \mathrm{Kr}, \mathrm{Xe}$ ) with

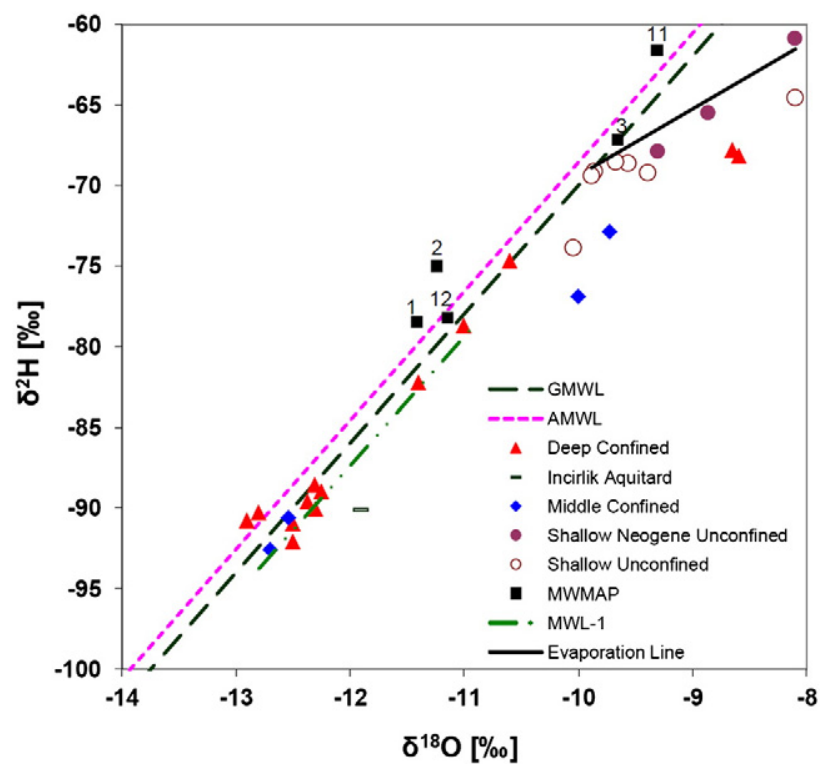

Figure 4. $\delta^{2} \mathrm{H}$ vs $\delta^{18} \mathrm{O}$ diagram. GMWL $=$ Global Meteoric Water Line (Craig, 1961); $\mathrm{AMWL}=$ Ankara Meteoric Water Line equation calculated from data in IAEA/WMO, $2004\left(\delta^{2} \mathrm{H}=8 * \delta^{18} \mathrm{O}+11.42\right) ; \quad$ MWL- $1=$ Meteoric Water Line equation $\delta^{2} \mathrm{H}=$ $8 * \delta^{18} \mathrm{O}+8.6$ calculated from data in this study; MWMAP (monthly weighted mean of Ankara precipitation; the numbers 1, 2, 3, 11 and 12 refer to calendar months January, February, March, November and December, respectively). 
Table 4

Aquifer material $\mathrm{U}$ and $\mathrm{Th}$ concentration data.

\begin{tabular}{|c|c|c|c|c|c|c|}
\hline \multirow{2}{*}{$\begin{array}{l}\text { Geologic } \\
\text { unit }\end{array}$} & \multirow[t]{2}{*}{ Lithology } & \multirow{2}{*}{$\begin{array}{l}\text { Sample } \\
\text { ID }\end{array}$} & \multicolumn{2}{|c|}{ UTM coordinates } & \multirow{2}{*}{$\begin{array}{l}\text { Th } \\
(\mathrm{ppm})\end{array}$} & \multirow{2}{*}{$\begin{array}{l}\mathrm{U} \\
(\mathrm{ppm})\end{array}$} \\
\hline & & & $\mathrm{x}$ & $\mathrm{y}$ & & \\
\hline \multirow[t]{8}{*}{$\begin{array}{l}\text { Asmalidere } \\
\text { member }\end{array}$} & $\begin{array}{l}\text { Consolidated green } \\
\text { mudstone }\end{array}$ & F-7 & 459226 & 4445303 & 5.20 & 1.51 \\
\hline & $\begin{array}{l}\text { Loose green } \\
\text { mudstone }\end{array}$ & $\mathrm{F}-8$ & 459224 & 4445300 & 4.68 & 1.36 \\
\hline & Green mudstone & F-9 & 459229 & 4445308 & 3.89 & 1.00 \\
\hline & $\begin{array}{l}\text { Organic laminated } \\
\text { mudstone }\end{array}$ & F-10 & 459229 & 4445308 & 3.23 & 1.25 \\
\hline & Nodular limestone & F-11 & 459229 & 4445308 & 2.95 & 1.11 \\
\hline & Clayey limestone & F-12 & 459229 & 4445308 & 4.07 & 2.54 \\
\hline & $\begin{array}{l}\text { Green mudstone } \\
\text { with organic matter }\end{array}$ & $\mathrm{F}-13$ & 459229 & 4445308 & 5.61 & 1.31 \\
\hline & Green mudstone & F-14 & 459229 & 4445308 & 3.65 & 1.37 \\
\hline \multirow[t]{5}{*}{$\begin{array}{l}\text { Fethiye } \\
\text { member }\end{array}$} & $\begin{array}{l}\text { Yellowish green } \\
\text { mudstone }\end{array}$ & IN-3 & 458541 & 4442937 & 2.02 & 0.85 \\
\hline & $\begin{array}{l}\text { Cream beige } \\
\text { mudstone }\end{array}$ & IN-4 & 458541 & 4442937 & 3.89 & 1.68 \\
\hline & $\begin{array}{l}\text { Yellow-cream-beige } \\
\text { sandy mudstone }\end{array}$ & IN-5 & 458614 & 4442908 & 3.31 & 1.38 \\
\hline & $\begin{array}{l}\text { Yellow-colored } \\
\text { limestone }\end{array}$ & IN-6 & 458655 & 4442935 & 2.37 & 1.59 \\
\hline & $\begin{array}{l}\text { Yellow-colored } \\
\text { mudstone }\end{array}$ & IN-7 & 458659 & 4442914 & 4.86 & 1.69 \\
\hline
\end{tabular}

three free parameters $(T, A, F)$ (Aeschbach-Hertig et al., 2000). According to this non-linear least squares method, a $\chi^{2}$-test is used to test the quality of fit of different models to describe the data within their uncertainty, and the model parameters that minimize $\chi^{2}$ are found (Aeschbach-Hertig et al., 1999; Ballentine and Hall, 1999). One sample yielding a probability $p<0.01$ was rejected (i.e., sample $\mathrm{D}-63 \mathrm{~A}) ; p$ is the probability to obtain a $\chi^{2}$-value equal or higher than the observed value with a correct model; see Table 5). All other samples provided acceptable fits with the PR- and CE-models ( 14 samples out of $15, \chi^{2}=17.4 ; p=0.23$ for CE-model and $\chi^{2}=22.6$ $p=0.07$ for PR-model). The CE model better describes the noble gas data set from the Kazan aquifer system with a minimum $\chi^{2}$ value. In Table 5, as defined by Aeschbach-Hertig et al. (2000), $F$ is equal to $v / q$ where $v$ is the ratio of the entrapped gas volumes in the final and initial stage and $q$ is the ratio of the dry gas pressure in the trapped gas to that in the free atmosphere. The noble gas temperatures (NGTs) calculated by using the $\mathrm{CE}$-model range from $3.2^{\circ} \mathrm{C}$ to $14.7^{\circ} \mathrm{C}$, the lower ones belonging to the samples from the deep aquifer system (Table 5 ).

Helium excess values are presented as radiogenic ${ }^{4} \mathrm{He}$ (excess $\mathrm{He}$ above the atmospheric He components predicted by the model; Table 5). ${ }^{4} \mathrm{He}$ excesses vary from $-0.17 \times 10^{-8} \mathrm{~cm}^{3}$ STP $\mathrm{g}^{-1}$ to $1523 \times 10^{-8} \mathrm{~cm}^{3} \mathrm{STP} \mathrm{g}^{-1}$.

\section{Discussion}

Noble gas temperatures

The samples from the recharge area (S-4, S-5, S-16 and S-19) show an average noble gas temperature of $14.1 \pm 0.4^{\circ} \mathrm{C}$. This value is close to today's ground temperature for the recharge area $\left(\sim 13^{\circ} \mathrm{C}\right)$ at an elevation of $1050 \mathrm{~m}$. The average ground temperature is calculated by using the daily soil temperature measurements taken $50 \mathrm{~cm}$ below ground between 1941 and 2006 from a station in Ankara (ground temperature: $\sim 14^{\circ} \mathrm{C}$; elevation: $891 \mathrm{~m}$; Turkish State Meteorological Service, personal communication), after correcting this temperature for the decrease in temperature from $891 \mathrm{~m}$ to $1050 \mathrm{~m}$. In Ankara station, ground temperatures are $2.2^{\circ} \mathrm{C}$ warmer than mean annual air temperatures.

NGTs calculated for samples S-2, S-3 and S-9, which are from the shallow system but under the influence of mixing with deeper waters as suggested by the geochemical and tracer data (SRK, 2004; Arslan et al., 2012), are 1.2 to $2.8^{\circ} \mathrm{C}$ lower than the ground temperatures at $1050 \mathrm{~m}\left(13^{\circ} \mathrm{C}\right)$.

The samples from the deep system are about 3 to $8^{\circ} \mathrm{C}$ lower than today's ground temperature for the recharge area $\left(11.7^{\circ} \mathrm{C}\right.$ for a recharge elevation of $1250 \mathrm{~m}$ ), indicating that some groundwater recharge occurred to the confined parts of this system under colder climatic conditions than at present.

\section{Stable isotopes}

For the shallow aquifer samples, the deviation from the GMWL is most likely caused by evaporative enrichment as the depth to groundwater is between 2 and $15 \mathrm{~m}$ in those wells (less than $2 \mathrm{~m}$ in well S-9 and around $15 \mathrm{~m}$ in S-5). Such evaporative enrichment

Table 5

Results of fitting Eq. (2) to the measured concentrations of Ne, Ar, Kr, Xe.

\begin{tabular}{|c|c|c|c|c|c|c|c|c|c|}
\hline Sample & $\chi^{2}$ & $p$ & $T\left[{ }^{\circ} \mathrm{C}\right]$ & $\mathrm{A}\left[\mathrm{cm}^{3} \cdot \mathrm{STP} / \mathrm{g}\right]$ & $F$ & $q$ & $\nu$ & $\Delta \mathrm{Ne}[\%]$ & Radiogenic He $\left[10^{-8} \mathrm{~cm}^{3} \cdot \mathrm{STP} / \mathrm{g}\right]$ \\
\hline S-2 & 0.31 & 0.58 & $11.63 \pm 0.6$ & 0.02 & 0.82 & 1.11 & 0.91 & 16.06 & $0.33 \pm 0.12$ \\
\hline$S-3$ & 3.25 & 0.07 & $11.76 \pm 0.4$ & 0.00 & 0.00 & 1.11 & 0.00 & 23.20 & $1195 \pm 24.1$ \\
\hline S-4 & 0.09 & 0.77 & $14.26 \pm 0.4$ & 0.00 & 0.13 & 1.11 & 0.14 & 20.06 & $17.26 \pm 0.46$ \\
\hline S-5 & 1.52 & 0.22 & $14.70 \pm 0.5$ & 0.01 & 0.73 & 1.12 & 0.81 & 16.47 & $-0.18 \pm 0.11$ \\
\hline S-9 & 0.17 & 0.68 & $10.19 \pm 0.4$ & 0.01 & 0.34 & 1.17 & 0.40 & 30.41 & $750 \pm 15.1$ \\
\hline S-11 & 0.01 & 0.93 & $12.40 \pm 0.5$ & 0.01 & 0.39 & 1.24 & 0.48 & 40.14 & $126 \pm 2.63$ \\
\hline S-16 & 1.04 & 0.31 & $13.89 \pm 4.2$ & 0.11 & 0.81 & 1.20 & 0.97 & 21.40 & $0.17 \pm 0.12$ \\
\hline S-19 & 5.93 & 0.02 & $13.44 \pm 0.4$ & 0.00 & 0.00 & 1.14 & 0.00 & 26.73 & $0.09 \pm 0.16$ \\
\hline D-8 & 0.29 & 0.59 & $6.16 \pm 0.5$ & 0.02 & 0.40 & 1.45 & 0.58 & 69.74 & $24.62 \pm 0.65$ \\
\hline D-13 & 0.05 & 0.82 & $5.42 \pm 0.4$ & 0.01 & 0.27 & 1.32 & 0.35 & 56.85 & $31.11 \pm 0.77$ \\
\hline D-33 & 0.00 & 0.95 & $8.54 \pm 0.5$ & 0.02 & 0.51 & 1.36 & 0.69 & 51.80 & $80.08 \pm 1.73$ \\
\hline D-37 & 0.03 & 0.87 & $5.18 \pm 0.4$ & 0.01 & 0.27 & 1.30 & 0.36 & 54.78 & $26.49 \pm 0.68$ \\
\hline D-47 & 2.81 & 0.09 & $8.45 \pm 0.5$ & 0.02 & 0.42 & 1.40 & 0.59 & 61.33 & $1523.2 \pm 30.6$ \\
\hline$D-63 A$ & 19.68 & 0.00 & $4.11 \pm 0.3$ & 0.01 & 0.00 & 1.29 & 0.00 & 63.82 & $4.05 \pm 0.29$ \\
\hline D-68R & 1.93 & 0.16 & $3.18 \pm 0.3$ & 0.01 & 0.01 & 1.31 & 0.01 & 63.17 & $4.58 \pm 0.3$ \\
\hline
\end{tabular}

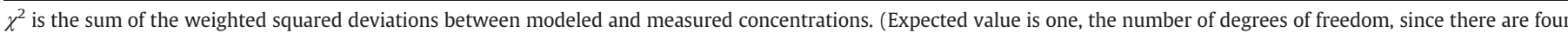
constraints ( $\mathrm{Ne}, \mathrm{Ar}, \mathrm{Kr}, \mathrm{Xe}$ ) and three free parameters (T, A, F) for each sample).

$p$ is the probability for $\chi^{2}$ to be equal to or larger than the actual value due to random errors, although the model is correct. Fits with $\mathrm{p}<0.01$ are rejected (values in italics).

$T$ is the model parameter for the equilibration temperature (noble gas temperature, NGT).

$A$ is the model parameter for the STP-volume of initially entrapped air per mass of water.

$F=v / q$ is the fractionation parameter, showing the reduction of the entrapped gas volume.

$v$ is the remaining fraction of the entrapped gas volume after partial dissolution.

$q$ is the dry gas pressure in the entrapped gas relative to that in the atmosphere.

$\Delta \mathrm{Ne}(\%)=\left(\mathrm{Ne}_{\text {meas }} / \mathrm{Ne}_{\mathrm{eq}}-1\right) \times 100 \%$ is the relative $\mathrm{Ne}$ excess above solubility equilibrium.

Radiogenic He is the excess He above the atmospheric He components predicted by the model. 
frequently occurs during or after recharge in arid regions (e.g., Clark and Fritz, 1997).

According to the relationship between $\delta^{18} \mathrm{O}$ and elevation obtained by Apaydin (2004) for Beypazari Trona Ore field, which is located $50 \mathrm{~km}$ west of the study area, the depletion in $\delta^{18} \mathrm{O}$ is about $0.44 \%$ per $100 \mathrm{~m}$ rise in altitude. In our study area, the average isotopic depletion in $\delta^{18} \mathrm{O}$ between shallow and deep systems is $2.5 \%$ and it is not possible to explain these isotopically lighter values in samples from the deeper groundwater systems solely with the altitude effect based on Apaydin's (2004) study. In fact, the highest topographical elevation in the recharge area is not as high as the elevation that would be obtained from $\delta^{18} \mathrm{O}$ data if their minimum values would be explained by the altitude in the recharge area of the shallow aquifer only. Therefore, it has been concluded that the lighter stable isotope values reflect that the recharge elevation of the deep aquifer system is higher than the shallow system (altitude effect) and the recharge temperatures in the deep aquifer system are lower than that in the shallow system (temperature effect). Since the elevation difference between shallow and deep systems is around $200 \mathrm{~m}$, about $0.9 \%$ of the depletion would be due to the elevation changes and the remainder (about 1.6\%) is a lower limit for the climateinduced change. Consequently, the differences in stable isotope ratios of groundwater from the shallow and deeper systems indicate that deep groundwaters were recharged under climatic conditions different from today's.

The temperature effect is one of the climate-related factors influencing the $\delta^{18} \mathrm{O}$ values and has to be taken account when interpreting $\delta^{18} \mathrm{O}$ data. This effect can be estimated using modern values obtained from the monitoring station of the IAEA/WMO network located in Ankara. Monthly mean values of $\delta^{18} \mathrm{O}$ and temperature at this station are correlated $(r=0.57)$ with a slope of $0.32 \pm$ $0.01 \% \circ{ }^{\circ} \mathrm{C}^{-1}$ (IAEA/WMO, 2004). Such strong relationships between $\delta^{18} \mathrm{O}$ and temperature can also be observed in other regions (e.g., Kabul, Tashkent, Irkutsk, Zagreb, and Krakow) that are under the influence of continental climate conditions similar to that of Ankara (IAEA, 1992).

A meteoric water line (MWL-1) with a deuterium excess (d) of $8.7 \%$ can be constructed by using the stable isotope data of samples D-13, D-37, D-47, D-60A, and D-63B from the deep aquifer system with an $r^{2}$ value of 0.98 (Fig. 4). The d value is somewhat different from that of modern Ankara precipitation, which is about $11.4 \%$. On a global basis the d-value averages about 10\% (Craig, 1961). However, it changes regionally due to variations in source of humidity, wind speed and sea-surface temperature (SST) (Clark and Fritz, 1997). According to Clark and Fritz (1997), when humidity is about $85 \%$ stable isotope values for precipitation plot very close to the global meteoric water line. It is hard to determine the deuterium excess values in precipitation of the Holocene or Pleistocene epochs with our present data set. However, in general, the deuterium excess seems to be more or less uniform throughout the record, suggesting a constant circulation regime of the atmosphere over the study area for the past $35{ }^{14} \mathrm{C}$ ka BP as suggested by Rozanski (1985). The general cooling during the late Pleistocene might be accompanied by a change in source of water vapor recharging the aquifer.

\section{Radiocarbon dating}

The radioactive isotope of carbon, ${ }^{14} \mathrm{C}$, is extensively used in dating of dissolved inorganic carbon (DIC) in groundwater $\left(\mathrm{DIC}=\mathrm{CO}_{2(\mathrm{aq})}+\mathrm{HCO}_{3}^{-}+\mathrm{CO}_{3}^{-2}\right)$ as the atmospheric ${ }^{14} \mathrm{C}$ dissolved in the precipitation reaches the groundwater table and starts decaying to nitrogen in the groundwater system. Its relatively long half-life of $5730 \mathrm{yr}$ allows dating of ages up to about 40,000 yr. To successfully date a groundwater sample by radiocarbon dating, the initial activity of ${ }^{14} \mathrm{C}$ should be known (Clark and Fritz, 1997). Estimation of the initial activity of ${ }^{14} \mathrm{C}\left(a_{0}{ }^{14} \mathrm{C}\right)$ requires radiocarbon data of a sample from the recharge area, which is proven to be modern but tritium-free pre-bomb water (Kazemi et al., 2006). During the hydrogeology studies for conceptual understanding of the study area, Yazicigil et al. (2001) gathered isotope data from some of the springs and wells. One of the sampled springs, SP-2, is a seasonal spring responding to precipitation immediately and ceases to flow during the dry season. For this spring, the ${ }^{3} \mathrm{H}$ amount, ${ }^{14} \mathrm{C}$ activity, and the $\delta^{13} \mathrm{C}$ value were reported in February, 2001 to be $7.58 \mathrm{TU}, 68 \mathrm{pmc}$ and $-8.96 \%$, respectively (Yazicigil et al., 2001). This modern sample contains tritium and there would be a slight overestimation of the initial condition for older groundwaters if $68 \mathrm{pmc}$ is used as $a_{0}{ }^{14} \mathrm{C}$, because of the presence of bomb ${ }^{14} \mathrm{C}$. Being aware of this fact, $a_{0}{ }^{14} \mathrm{C}$ was assumed to be $68 \mathrm{pmc}$ for all the samples during calculations (Table 2).

To simply use the first-order kinetic rate law for decay to date a groundwater sample, the final concentration of ${ }^{14} \mathrm{C}$ in groundwater should have only been affected by radioactive decay, although it can be modified by isotopic exchange from recrystallization and precipitation reactions. In our study area, there is evolution of DIC in the groundwaters and the influence of this evolution on $\delta^{13} \mathrm{C}$ values can be observed in Fig. 5. The evolution of DIC and the enrichment in $\delta^{13} \mathrm{C}$ between shallow and deep aquifer systems implies isotope exchange between groundwater and the aquifer matrix. There is possible dissolution of carbonate minerals adding dead carbon to the groundwater, resulting in a lower ${ }^{14} \mathrm{C}$ ratio for the sample. Therefore, ${ }^{14} \mathrm{C}$ ages need to be corrected for carbonate dissolution. There are different approaches to correct apparent ${ }^{14} \mathrm{C}$ ages and the most appropriate approach depends on the geochemical system and the data available. ${ }^{13} \mathrm{C}$ is a good tracer of open and closed system evolution of DIC in groundwater; the large difference in $\delta^{13} \mathrm{C}$ between the soil-derived DIC and carbonate minerals in the aquifer provide a reliable measure of ${ }^{14} \mathrm{C}$ dilution by carbonate dissolution. Therefore, in this study a $\delta^{13} \mathrm{C}$ mixing model was used (Pearson, 1965; Pearson and Hanshaw, 1970) to correct our ${ }^{14} \mathrm{C}$ ages. This model is strongly dependent on recharge conditions affecting the ${ }^{13} \mathrm{C}$ enrichment factor during dissolution of $\mathrm{CO}_{2}$ and the evolution of $\delta^{13} \mathrm{C}_{\text {DIC. }}$. Any process that adds to, removes from, or exchanges carbon with the DIC pool altering the ${ }^{14} \mathrm{C}$ concentrations will also affect its ${ }^{13} \mathrm{C}$ values. A dilution factor (q) as suggested by Pearson and Hanshaw (1970) was employed during our calculations as a measure of carbonate dissolution in the aquifer. This factor can be calculated by using Eq. (2). In this equation, $\delta^{13} C_{D I C}$ is measured ${ }^{13} \mathrm{C}$ in groundwater; $\delta^{13} C_{\text {soil }}$ is $\delta^{13} \mathrm{C}$ of the soil $\mathrm{CO}_{2}$ (depends on the vegetation, $\mathrm{C}_{3}$ plants $-27 \%$;

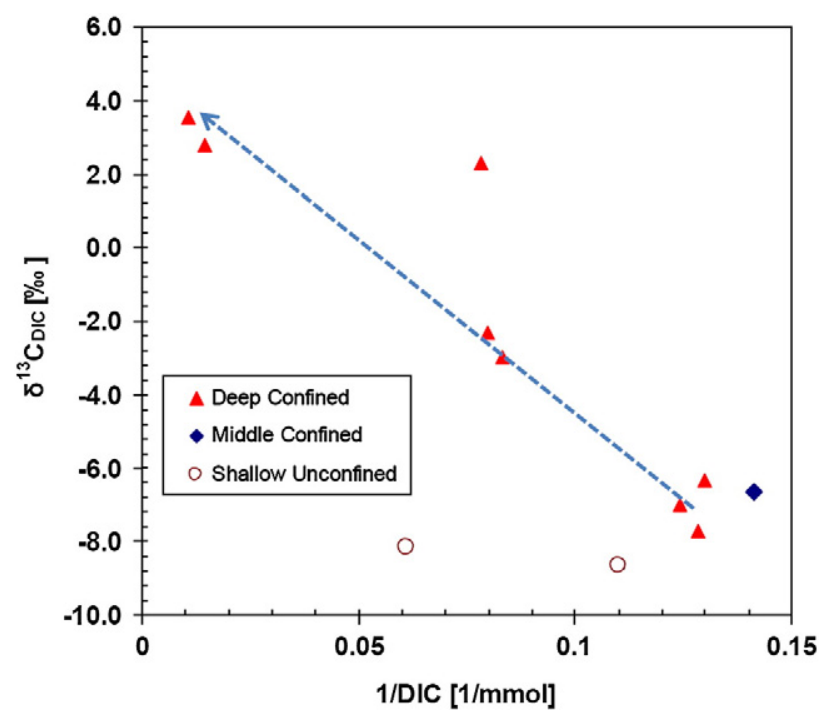

Figure 5. $\delta^{13} \mathrm{C}_{\mathrm{DIC}}$ Vs $1 / \mathrm{DIC}$ (dissolved inorganic carbon) graph showing the evolution of DIC in the groundwaters of Kazan Trona Basin. 
$\mathrm{C}_{4}$ plants approximately $-12.5 \%$ ); and $\delta^{13} C_{\text {carb }}$ is $\delta^{13} \mathrm{C}$ of the calcite being dissolved (usually close to $0 \%$; $2 \%$ for marine carbonates).

$q=\frac{\delta^{13} C_{D I C}-\delta^{13} C_{c a r b}}{\delta^{13} C_{\text {soil }}-\delta^{13} C_{c a r b}}$

We do not have any information regarding $\delta^{13} C_{\text {carb }}$ values of the carbonates in the study area; however, they should have a value similar to that measured for the carbonates located near the study area and deposited at the same time with the Eocene carbonates in the area. In a study carried out by Genc (2006) in Kirsehir, located in central Anatolia, Turkey, $\delta^{13} \mathrm{C}$ values of Lutetian carbonates ranged from $+2.1 \%$ o to $+2.2 \%$. Kirsehir is located in central Anatolia, just like the Kazan Basin, and the carbonates in question are of the same age. This value can be greater than $+2.2 \%$ for some other carbonates deposited in the central Anatolia because the Mesozoic marine dolomitic limestones in Konya Closed Basin have $\delta^{13} \mathrm{C}$ values of $+4.21 \%$ (Bayari et al., 2009). Therefore, it is not unreasonable to assume a value of $+4 \%$ for $\delta^{13} C_{\text {carb }}$ for the carbonates in the study area. Such an assumption also can explain the positive $\delta^{13} C_{D I C}$ values of samples D-57A, D-47 and D-8.

From field observations and other studies carried out around Ankara (Cetin et al., 2002; Elci and Erik, 2005) the modern plant species should follow a $C_{3}$ pathway as their principal photosynthesis cycle. Therefore, the modern $\delta^{13} C_{\text {soil }}$ value should be around $-27 \%$; however, $\delta^{13} C_{\text {soil }}$ values might not be constant over time. Botteme and van Zeist (1981), Prentice et al. (1992) and Wick et al. (2003) pointed out a low content of arboreal pollen and relatively high content of Chenopodiaceous pollen in the late Pleistocene record (especially from $30 \mathrm{ka}$ to $15 \mathrm{ka}$ ) in lakes Karamik and Sogut from western Turkey, Lake Ioannina from northern Mediterranean, and Lake Van from eastern Turkey, respectively. During this period, cold arid climate caused the dominance of the steppe vegetation $\left(C_{3}\right.$ plants) which is a type similar to the one around the study area today. Pollen evidence from Lake Eski Acigol and Lake Van region shows that arboreal vegetation re-established itself slowly in central Turkey during the Holocene (Wick et al., 2003; Woldring and Bottema, 2003). Therefore, the $\delta^{13} C_{\text {soil }}$ value might have changed in the past due to the change in vegetation cover; however, it probably was close to $-27 \%$ especially between $30 \mathrm{ka}$ and $15 \mathrm{ka}$.

$q$ values calculated accordingly are presented in Table 2 together with the estimates of ages through ${ }^{14} \mathrm{C}$ dating obtained by using Eq. (3). According to Table 2, all the samples from the middle and deep aquifer systems, except for sample D-20, entered the system before the Holocene. This observation is consistent with the findings extracted from the noble gas data. It should be noted that our age estimates derived from ${ }^{14} \mathrm{C}$ dating are likely lower limits because most measurements are only slightly above the detection limit. Moreover, the calculated ${ }^{14} \mathrm{C}$ ages should not be considered as absolute ages due to the uncertainties associated with the amount of dead carbon contribution, the vegetation cover in the area and the $\delta^{13} \mathrm{C}$ value for the carbonate rocks in the area.

$t=-8267 \ln \left(\frac{a_{t}{ }^{14} C}{q * a_{0}{ }^{14} C}\right)$

\section{Climate signals in noble gas and stable isotope records}

NGTs from the deep aquifer system of Kazan Trona Basin together with the stable isotope data suggest the presence of water from the last glacial period (LGP). The plot of $\delta^{18} \mathrm{O}$ vs NGT (Fig. 6) shows a linear correlation $(r=0.84)$ with a slope of $0.35 \pm 0.07 \%{ }^{\circ} \mathrm{C}^{-1}$. This correlation suggests that there is a climate signal in the $\delta^{18} \mathrm{O}$ data obtained in this study. As stated above, modern monthly mean values

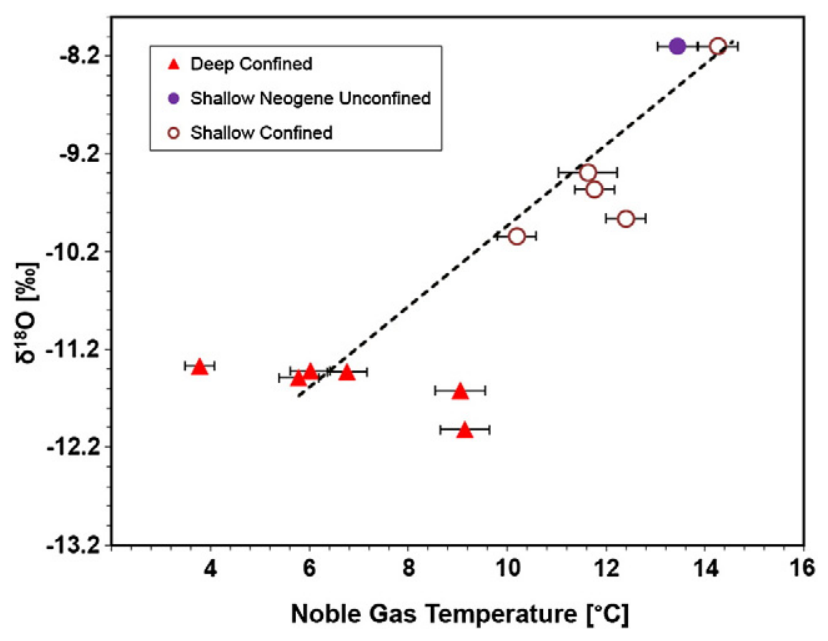

Figure 6. The correlation between $\delta^{18} \mathrm{O}$ and NGT. There is a good correlation between $\delta^{18} \mathrm{O}$ and NGT $(r=0.84)$ with a slope of $(0.35 \pm 0.07) \%{ }^{\circ} \mathrm{C}^{-1}$ (the error is $\pm 1 \mathrm{SE}$ ). The $\delta^{18} \mathrm{O}$ and NGT data for the deep aquifer samples are modified to eliminate the elevation effect. See text for details.

of $\delta^{18} \mathrm{O}$ and temperature at Ankara station are correlated with a slope of $0.32 \pm 0.0 \%{ }^{\circ} \mathrm{C}^{-1}$ (IAEA/WMO, 2004), which is similar to the one obtained by using the NGTs and $\delta^{18} \mathrm{O}$ data from our groundwater samples $\left(0.35 \pm 0.07 \% \circ{ }^{\circ} \mathrm{C}^{-1}\right)$. Thus, it can be concluded that the $\delta^{18} \mathrm{O}$ signal reflects a temperature effect close to that of the modern $\delta^{18} \mathrm{O}$ temperature relationship. It should be noted that since data from different aquifers are compared in this study, an elevation correction had to be carried out for samples from the deep aquifer system since using different recharge elevations introduces a systematic offset between shallow and deep samples. For this purpose, the deep aquifer samples $\delta^{18} \mathrm{O}$ and NGT data were modified in Figure 6 and $0.88 \%$ was added to $\delta^{18} \mathrm{O}$ data (as there is $0.44 \%$ o decrease in $\delta^{18} \mathrm{O}$ per $100 \mathrm{~m}$ rise in altitude) and $0.6^{\circ} \mathrm{C}$ was added to NGT data (as there is $0.3^{\circ} \mathrm{C}$ decrease in NGT per $100 \mathrm{~m}$ rise in altitude) to eliminate the effects of the recharge elevation difference between shallow and deep aquifer systems.

Data are clustered around three points with low $\delta^{18} \mathrm{O}$ and NGT values centered at $-11.50 \%$ and $6^{\circ} \mathrm{C}$, high $\delta^{18} \mathrm{O}$ and NGT values centered at $-9.60 \%$ and $11^{\circ} \mathrm{C}$, and $-8.20 \%$ and $13^{\circ} \mathrm{C}$, respectively (Fig. 6). The samples from the deep aquifer system display a wide range of NGTs ranging from $3.8^{\circ} \mathrm{C}$ to $9.1^{\circ} \mathrm{C}$ although the $\delta^{18} \mathrm{O}$ values

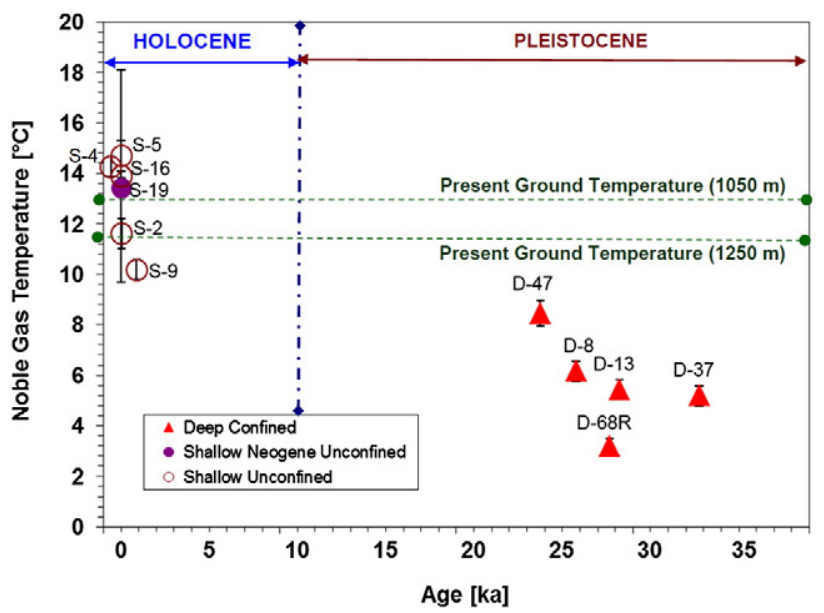

Figure 7. The ages obtained by ${ }^{14} \mathrm{C}$ and ${ }^{3} \mathrm{H} /{ }^{3} \mathrm{He}$ dating vs noble gas temperatures. Modern samples from the shallow system have NGTs close to today's ground temperatures $\left(13^{\circ} \mathrm{C}\right.$ for $1050 \mathrm{~m}$ implied by soil temperatures, $11.7^{\circ} \mathrm{C}$ for $1250 \mathrm{~m}$ predicted by using an environmental lapse rate of $6.5^{\circ}$ in $1000 \mathrm{~m}$ ) whereas the samples with high ${ }^{14} \mathrm{C}$ ages have lower NGTs. 
are more or less similar. There is also a strong relationship between the ages obtained by ${ }^{14} \mathrm{C}$ and ${ }^{3} \mathrm{H} /{ }^{3} \mathrm{He}$ dating and NGTs (Fig. 7). Details of ${ }^{3} \mathrm{H} /{ }^{3} \mathrm{He}$ age calculations can be found in Arslan et al. (2012). Recently recharged waters with the isotopic signature of modern precipitation from the shallow system have NGTs close to today's mean ground temperatures $\left(13^{\circ} \mathrm{C}\right)$ whereas the isotopically lighter samples with high ${ }^{14} \mathrm{C}$ ages have lower NGTs. The depletion in heavy isotopes of the groundwaters with ${ }^{14} \mathrm{C}$ ages of about $15 \mathrm{cal} \mathrm{ka}$ $\mathrm{BP}$ and older, in comparison with more recently recharged waters, indicates the presence of paleorecharge to the deeper systems (Fig. 7).

The radiogenic helium values presented in Table 5 are compared with the age estimates based on ${ }^{3} \mathrm{H} /{ }^{3} \mathrm{He}$ and radiocarbon and NGTs (Figs. 8 and 9). Non-atmospheric ${ }^{4} \mathrm{He}$ concentrations can be used as a relative age indicator (He concentrations increase with groundwater age due to accumulation of radiogenic ${ }^{4} \mathrm{He}$ produced $U$ and Th decay series elements in the rocks and released into groundwater or ${ }^{4} \mathrm{He}$ accumulated from crustal or mantle helium fluxes; e.g., Torgersen and Stute, in press). The internal rate of ${ }^{4} \mathrm{He}$ production from U/Th-series decay were calculated roughly by using an average density of $2.5 \mathrm{~g} \mathrm{~cm}^{-3}, 20 \%$ rock porosity and $1.43 \mathrm{ppm}$ and $3.82 \mathrm{ppm} U$ and Th concentrations, respectively, in aquifer material. $U$ and Th concentrations were obtained by averaging a total of 13 measurements carried out in aquifer material samples. The production rate was calculated to be $3.5 \times 10^{-12} \mathrm{~cm}^{3}$ STP $\mathrm{g}^{-1} \mathrm{yr}^{-1}$, which is slightly below the typical in situ production rate reported as $5 \times 10^{-12} \mathrm{~cm}^{3}$ STP $\mathrm{g}^{-1} \mathrm{yr}^{-1}$ (e.g., Torgersen and Clarke, 1985). Samples from the deep aquifer system except for sample D-47 are consistent with the accumulation of internally produced He (Fig. 8). Sample D-47 is different from the rest of the samples, as indicated above, and its He excess indicates that the mean residence time of this sample is higher than the estimated radiocarbon age.

When plotted as a function of helium excess, the NGTs show a smooth trend (Fig. 9). NGTs increase with increasing He excess values, which is interpreted as indication of gradual cooling from the pre-LGM to the LGM period. In the same figure, the shallow samples show varying He excess values, although the NGTs are similar. The modern samples (S-2, S-5, S-16, S-19) have very little excess He while some of the shallow samples (S-3, S-4, S-9, S-11) have high NGTs and high He excess values likely reflecting mixing between mostly groundwater of Holocene origin with some older glacial groundwater (Fig. 9).

There is a clear distinction between the shallow and deep samples in terms of excess air (Table 5) and the deep samples have distinctly

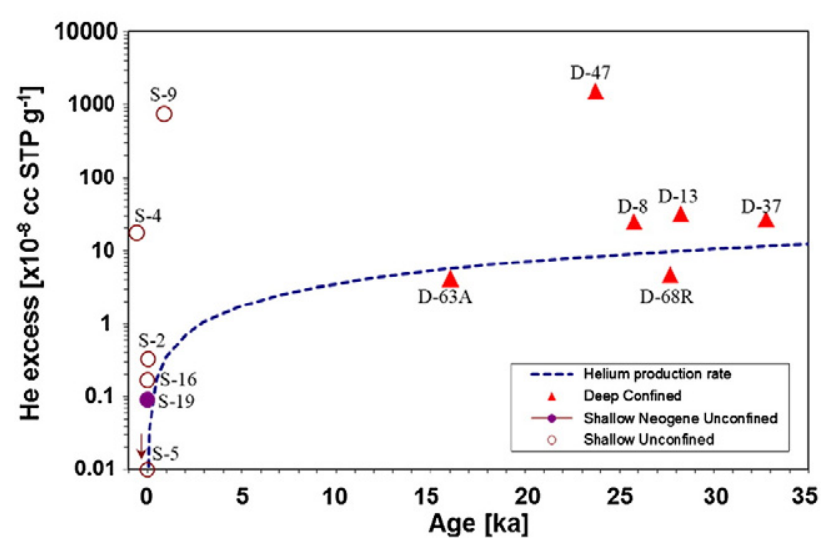

Figure 8. Helium excess (terrigenic He) vs. estimates of ages through ${ }^{3} \mathrm{H} /{ }^{3} \mathrm{He}$ dating (Arslan et al., 2012) and radiocarbon dating. Most samples from the deep aquifer system follow the trend that He-excess increases with age. The calculated helium production rate is $3.5 \times 10^{-12} \mathrm{~cm}^{3} \mathrm{STP} \mathrm{g}^{-1} \mathrm{yr}^{-1}$.

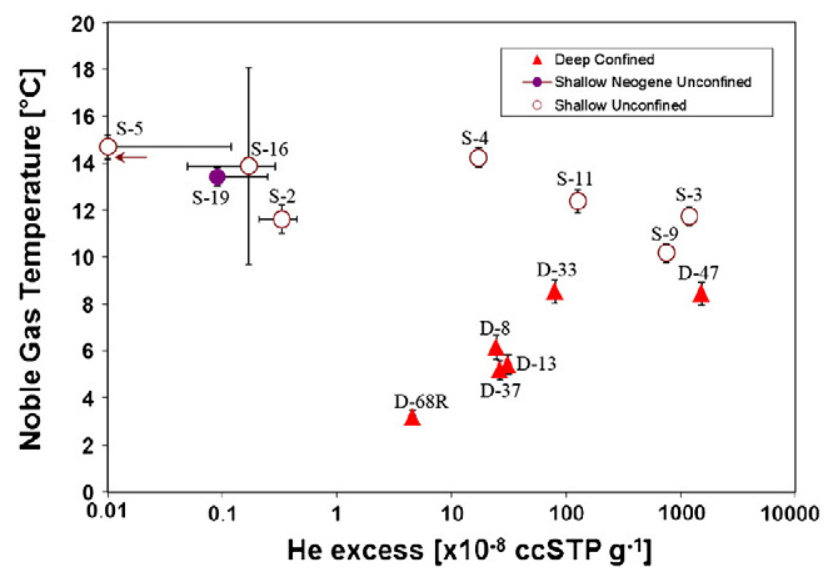

Figure 9. Noble gas temperatures (NGTs) vs. helium excesses. There is a correlation between noble gas temperatures and He-excesses for the deep aquifer system. For the shallow system, although the NGTs are more or less the same, He-excess values vary due to the mixing of older groundwater.

higher $\Delta \mathrm{Ne}$ values. The amount of excess air is linked to the amplitude of groundwater table fluctuations due to intermittent rainfall patterns (Heaton and Vogel, 1981). Therefore, higher $\Delta$ Ne values observed in deep groundwater samples indicate that the recharge dynamics in the deep system were different in the past and the recharge and precipitation amounts were more variable, causing large fluctuations of the water table.

In the study area, there is not much information on late Pleistocene paleoclimate. In fact, our NGT record is the first data set of this nature from central Turkey. Besides, no study carried out in central Anatolia describes the temperatures in Pleistocene extending beyond the LGM period that can be used for comparison. However, there is a study by Affek et al. (2008) in Soreq cave speleothems (Israel) that reports temperatures $6-7^{\circ} \mathrm{C}$ colder than modern-day temperatures. Affek et al. (2008) stated that about $56 \mathrm{ka}$ ago the temperatures were $3^{\circ} \mathrm{C}$ colder during pre-LGM than the modern temperatures. Also, NGT records obtained from different locations in Europe and Southeastern Arabia (Great Hungarian Plain-Hungary, Northern Oman, Ledo-Paniselian Aquifer-Belgium, Pannonian Basin-Hungary and Bohemian Cretaceous Basin-Czech Republic) revealed similar temperature changes $\left(5-9^{\circ} \mathrm{C}\right)$ between glacial periods and the Holocene (Stute and Deak, 1989; Weyhenmeyer et al., 2000; Blaser et al., 2010; Alvarado et al., 2011; Varsanyi et al., 2011).

\section{Conclusions}

The stable isotope, noble gas and ${ }^{14} \mathrm{C}$ data from the Kazan Trona Ore Field verify the existence of paleowater in the deep aquifer system. The noble gas temperatures (NGTs) of the shallow aquifer system are consistent with the average annual ground temperatures whereas in the deep groundwater system NGTs 4 to $8^{\circ} \mathrm{C}$ lower than at present are observed. The estimated radiocarbon ages are modern for the samples from the shallow system and up to 34 cal ka BP in the middle and deep aquifer systems. Helium excess values are consistent with the accumulation of internally produced He. In one sample the He excess value indicates that the mean residence time of the sample is higher than the estimated radiocarbon age. The mean residence times, together with the stable isotope data, provide strong evidence of recharge to the middle and deep aquifer systems under colder climatic conditions, as compared to the present. Our data support previous studies on paleoclimate in central Turkey indicating that glacial periods were 5 to $8^{\circ} \mathrm{C}$ cooler than present. Moreover, a different deuterium excess value (8.7\%) than today's 
(11.42\% for Ankara) indicates that the general cooling during the last Pleistocene might be accompanied by a change in source of water vapor recharging the aquifer.

\section{Acknowledgments}

This study was supported by The Scientific and Technological Research Council of Turkey Environmental, Atmospheric, Earth and Marine Sciences Research Group (CAYDAG) Short-Term R\&D Funding Programme (1002) Project no. 106Y310. Sebnem Arslan was supported by the fellowship of Fulbright Commission of Turkey during her research at Lamont-Doherty Earth Observatory. The assistance of Faruk Suluki, Omer Kahraman, Ugur Ozturk, Baki Varol, Zehra Karakas and Elif Gunen in the field and the help provided by Zhongqi Cheng during $U$ and Th measurements in Brooklyn College are appreciated. We thank Riotur Mining Inc. for giving us access to the hydrogeologic and hydrochemical data. The comments of Quaternary Research Journal's Associate Editor Jay Quade and two anonymous reviewers are also gratefully acknowledged.

\section{References}

Aeschbach-Hertig, W., Peeters, F., Beyerle, U., Kipfer, R., 1999. Interpretation of dissolved atmospheric noble gases in natural waters. Water Resources Research 35, 2779-2792.

Aeschbach-Hertig, W., Peeters, F., Beyerle, U., Kipfer, R., 2000. Palaeotemperature reconstruction from noble gases in ground water taking into account equilibration with entrapped air. Nature 405, 1040-1044.

Aeschbach-Hertig, W., Stute, M., Clark, J.F., Reuter, R.F., Schlosser, P., 2002. A paleotemperature record derived from dissolved noble gases in groundwater of the Aquia Aquifer (Maryland, USA). Geochimica et Cosmochimica Acta 66, 797-817.

Affek, H.P., Bar-Matthews, M., Ayalon, A., Matthews, A., Eiler, J.M., 2008. Glacial/interglacial temperature variations in Soreq cave speleothems as recorded by 'clumped isotope' thermometry. Geochimica et Cosmochimica Acta 72, 5351-5360.

Alley, R.B., Marotzke, J., Nordhaus, W.D., Overpeck, J.T., Peteet, D.M., Pielke, R.A., Pierrehumbert, R.T., Rhines, P.B., Stocker, T.F., Talley, L.D., Wallace, J.M., 2003. Abrupt climate change. Science 299, 2005-2010.

Alvarado, J.A.C., Leuenberger, M., Kipfer, R., Paces, T., Purtschert, R., 2011. Reconstruction of past climate conditions over central Europe from groundwater data. Quaternary Science Reviews 30, 3423-3429.

Andrews, J.N., Lee, D.J., 1979. Inert-gases in groundwater from the Bunter sandstone of England as indicators of age and paleoclimatic trends. Journal of Hydrology 41, 233-252.

Apaydin, A., 2004. Study of recharge and conditions of Cakiloba-Karadoruk aquifer system (western Beypazari-Ankara). PhD Thesis, Hacettepe University, Ankara, 147 pp.

Arslan, S., 2008. Investigation of the recharge and discharge mechanisms of a complex aquifer system by using environmental isotopes and noble gases. PhD Thesis, Middle East Technical University, Ankara, 180 pp.

Arslan, S., Yazicigil, H., Stute, M., Schlosser, P., Smethie, W.M., 2012. Groundwater dynamics in the complex aquifer system of Kazan Trona Ore Field, Ankara, Turkey. Manuscript to be submitted for publication in Hydrogeology Journal.

Ballentine, C.J., Hall, C.M., 1999. Determining paleotemperature and other variables by using an error-weighted, nonlinear inversion of noble gas concentrations in water. Geochimica et Cosmochimica Acta 63, 2315-2336.

Bar-Matthews, M., Ayalon, A., Gilmour, M., Matthews, A., Hawkesworth, C.J., 2003. Sealand oxygen isotopic relationships from planktonic foraminifera and speleothems in the Eastern Mediterranean region and their implication for paleorainfall during interglacial intervals. Geochimica et Cosmochimica Acta 67, 3181-3199.

Bayari, C.S., Ozyurt, N.N., Kilani, S., 2009. Radiocarbon age distribution of groundwater in Konya Closed Basin, central Anatolia, Turkey. Hydrogeology Journal 17, 347-365.

Beyerle, U., Purtschert, R., Aescbach-Hertig, W., Imboden, D.M., Loosli, H.H., Wieler, R., Kipfer, R., 1998. Climate and groundwater recharge during the last glaciation in an ice-covered region. Science 282, 731-734.

Blaser, P.C., Kipfer, R., Loosli, H.H., Walraevens, K., Van Camp, M., Aeschbach-Hertig, W., 2010. A $40 \mathrm{ka}$ record of temperature and permafrost conditions in northwestern Europe from noble gases in the Ledo-Paniselian Aquifer (Belgium). Journal of Quaternary Science 25, 1038-1044.

Botteme, S., van Zeist, W., 1981. Palynological evidence of the climatic history of the Near East, 50,000-6000 BP. Colloques Internationaux de C.N.R.S., Paris 598, 111-132.

Camur, M.Z., Er, C., Yazicigil, H., 2008. Modeling of lithology induced chemical anomalies in the aquifer systems of the Kazan Trona deposit area, Ankara, Turkey. Environmental Geology 54, 777-789.

Castro, M.C., Hall, C.M., Patriarche, D., Goblet, P., Ellis, B.R., 2007. A new noble gas paleoclimate record in Texas - basic assumptions revisited. Earth and Planetary Science Letters 257, 170-187.

Cetin, B., Unc, E., Uyar, G., 2002. The moss flora of Ankara-Kizilcahamam-Camkoru and Camlidere Districts. Turkish Journal of Botany 26, 91-101.

Clark, I., Fritz, P., 1997. Environmental Isotopes in Hydrogeology. CRC Press, Boca Raton . (352 pp.)
Clark, J.F., Stute, M., Schlosser, P., Drenkard, S., 1997. A tracer study of the Floridan aquifer in southeastern Georgia: implications for groundwater flow and paleoclimate. Water Resources Research 33, 281-289.

Clarke, W.B., Jenkins, W.J., Top, Z., 1976. Determination of tritium by mass-spectrometric measurement of He-3. International Journal of Applied Radiation and Isotopes 27 515-522.

Krypton, xenon and radon: gas solubilities. : Clever, H.L. (Ed.), 1979. International Union of Pure and Applied Chemistry, Solubility Data Series, vol. 2. Pergamon Press, Oxford (357 pp.).

Craig, H., 1961. Isotopic variations in meteoric waters. Science 133, 1702-1703.

Drimmie, R.J., Heemskerk, A.R., 2001. Stable oxygen isotope ratios by carbon dioxide equilibration automatic, continuous flow, isotope ratio mass spectrometry. Technical Procedure 13.1 Rev 00. Environmental Isotope Laboratory, Department of Earth Sciences, University of Waterloo.

Drimmie, R.J., Shouakar-Stash, O., Walters, R., Heemskerk, A.R., 2001. Hydrogen Isotope Ratio by Automatic, Continuous Flow, Elemental Analyses, and Isotope Ratio Mass Spectrometry. University of Waterloo, Ontario, Canada.

Elci, B.T., Erik, S., 2005. Flora of Kirmir Valley (Gudul, Ankara). Turkish Journal of Botany 29, 435-461.

Emeis, K.C., Struck, U., Schulz, H.M., Rosenberg, R., Bernasconi, S., Erlenkeuser, H., Sakamoto, T., Martinez-Ruiz, F., 2000. Temperature and salinity variations of Mediterranean Sea surface waters over the last 16,000 years from records of planktonic stable oxygen isotopes and alkenone unsaturation ratios. Paleogeography, Paleoclimatology, Paleoecology 158, 259-280.

Genc, Y., 2006. Genesis of the Neogene interstratal karst-type Pohrenk fluorite-barite (+/lead) deposit (Kirsehir, Central Anatolia, Turkey). Ore Geology Reviews 29, 105-117.

Hall, C.M., Castro, M.C., Lohmann, K.C., Ma, L., 2005. Noble gases and stable isotopes in a shallow aquifer in southern Michigan: implications for noble gas paleotemperature reconstructions for cool climates. Geophysical Research Letters 32, L18404.

Heaton, T.H.E., Vogel, J.C., 1981. Excess air in groundwater. Journal of Hydrology 50, 201-216.

IAEA, 1992. Statistical Treatment of Data in Environmental Isotopes in Precipitation. International Atomic Energy Agency.

IAEA/WMO, 2004. Global Network of Isotopes in Precipitation, the GNIP Database. International Atomic Energy Agency.

Jones, M.D., Roberts, C.N., Leng, M.J., 2007. Quantifying climatic change through the last glacial-interglacial transition based on lake isotope palaeohydrology from central Turkey. Quaternary Research 67, 463-473.

Kazemi, G.A., Lehr, J.H., Perrochet, P., 2006. Groundwater Age. John Wiley \& Sons, Inc., Canada . (346 pp.).

Klump, S., Grundl, T., Purtschert, R., Kipfer, R., 2008. Groundwater and climate dynamics derived from noble gas, C-14, and stable isotope data. Geology 36 395-398.

Kuzucuoglu, C., Bertaux, J., Black, S., Denefle, M., Fontugne, M., Karabiyikoglu, M. Kashima, K., Limondin-Lozouet, N., Mouralis, D., Orth, P., 1999. Reconstruction of climatic changes during the Late Pleistocene, based on sediment records from the Konya Basin (Central Anatolia, Turkey). Geological Journal 34, 175-198.

Ludin, A., Weppernig, R., Boenisch, G., Schlosser, P., 1997. Mass Spectrometric Measurement of Helium Isotopes and Tritium. Lamont-Doherty Earth Observatory, New York

Mazor, E., 1972. Paleotemperatures and other hydrological parameters deduced from noble-gases dissolved in groundwaters - Jordan Rift Valley, Israel. Geochimica et Cosmochimica Acta 36, 1321-1336.

Pearson, F.J., 1965. Use of C-13/C-12 Ratios to Correct Radiocarbon Ages of Material Initially Diluted by Limestone. 6th International Conference on Radiocarbon and Tritium Dating, Pullman, Washington. 357 pp.

Pearson, F.J., Hanshaw, B.B., 1970. Sources of dissolved carbonate species in groundwater and their effects on Carbon-14 dating, isotope hydrology. IAEA Symposium 129 Vienna, pp. 271-286.

Prentice, I.C., Guiot, J., Harrison, S.P., 1992. Mediterranean vegetation, lake levels and palaeoclimate at the Last Glacial Maximum. Nature 360, 658-660.

Roberts, N., Reed, J.M., Leng, M.J., Kuzucuoglu, C., Fontugne, M., Bertaux, J., Woldring, H. Bottema, S., Black, S., Hunt, E., Karabiyikoglu, M., 2001. The tempo of Holocene climatic change in the eastern Mediterranean region: new high-resolution craterlake sediment data from central Turkey. The Holocene 11, 721-736.

Rojay, B., Toprak, V., Bozkurt, E., 2002. Core Sample Analysis in Kazan Soda Project Area. Middle East Technical University, Ankara.

Rozanski, K., 1985. Deuterium and O-18 in European groundwaters - links to atmospheric circulation in the past. Chemical Geology 52, 349-363.

Sarikaya, M.A., Zreda, M., Ciner, A., 2009. Glaciations and paleoclimate of Mount Erciyes, central Turkey, since the Last Glacial Maximum, inferred from (36)C cosmogenic dating and glacier modeling. Quaternary Science Reviews 28 2326-2341.

SRK, 2001. Hydrogeology, Conceptual Understanding. Kazan Trona Project, Ankara.

SRK, 2004. Hydrogeological Modeling. Kazan Trona Project, Ankara.

Stute, M., Clark, J.F., Schlosser, P., Broecker, W.S., Bonani, G., 1995. A 30,000 year continental paleotemperature record derived from noble gases dissolved in groundwater from the San-Juan Basin, New Mexico. Quaternary Research 43, 209-220.

Stute, M., Deak, J. 1989. Environmental isotope study (C-14 C-13, O-18, D, noble gases) on deep groundwater circulation systems in Hungary with reference to paleoclimate. Radiocarbon 31, 902-918.

Stute, M., Forster, M., Frischkorn, H., Serejo, A., Clark, J.F., Schlosser, P., Broecker, W.S. Bonani, G., 1995. Cooling of tropical Brazil (5-degrees-C) during the last glacial maximum. Science 269, 379-383.

Stute, M., Schlosser, P., 1993. Principles and applications of the noble gas paleothermometer. Climate Change in Continental Isotopic Records. : In: Swart, 
P.K., Lohmann, K.C., McKenzie, J., Savin, S. (Eds.), Geophysical Monograph, 78 American Geophysical Union, Washington DC, pp. 89-100.

Stute, M., Schlosser, P., Clark, J.F., Broecker, W.S., 1992. Paleotemperatures in the southwestern United States derived from noble-gases in ground-water. Science 256, 1000-1003.

Toprak, V., Rojay, B., 2000. Geology Baseline Study for the Kazan Soda Project Area. Middle East Technical University, Ankara.

Toprak, V., Rojay, B., 2001. Geological Investigation in Kazan Soda Project Area. Middle East Technical University, Ankara.

Torgersen, T., Clarke, W.B., 1985. Helium accumulation in groundwater, I: an evaluation of sources and the continental flux of crustal $4 \mathrm{He}$ in the Great Artesian Basin, Australia. Geochimica et Cosmochimica Acta 49, 1211-1218.

Torgersen T., Stute, M., in press. Helium (and other noble gases) as a tool for understanding long time-scale groundwater transport. In: Suckow, A. (Ed), Dating Old Groundwater: A Guidebook, International Atomic Energy Agency, Vienna, pp. 196-233.

Varsanyi, I., Palcsu, L., Kovacs, L.O., 2011. Groundwater flow system as an archive of palaeotemperature: noble gas, radiocarbon, stable isotope and geochemical study in the Pannonian Basin, Hungary. Applied Geochemistry 26, 91-104.

Weiss, R.F., 1968. Piggyback samplers for dissolved gas studies on sealed water samples. Deep Sea Research 15, 695-699.

Weiss, R.F., 1970. The solubility of nitrogen, oxygen and argon in water and seawater. Deep Sea Research 17, 721-735.
Weiss, R.F., 1971. Solubility of helium and neon in water and seawater. Journal of Chemical and Engineering Data 16, 235-241.

Weiss, R.F., Kyser, T.K., 1978. Solubility of krypton in water and seawater. Journal of Chemical and Engineering Data 23, 69-72.

Weyhenmeyer, C.E., Burns, S.J., Waber, H.N., Aeschbach-Hertig, W., Kipfer, R., Loosli, H.H., Matter, A., 2000. Cool glacial temperatures and changes in moisture sources recorded in Oman groundwaters. Science 287, 842-845.

WHOI, 1989. Woods Hole Oceanographic Institution-National Ocean Sciences Accelerator Mass Spectrometry Facility (NOSAMS).

Wick, L., Lemcke, G., Sturm, M., 2003. Evidence of Late Glacial and Holocene climatic change and human impact in eastern Anatolia: high resolution pollen, charcoal, isotopic and geochemical records from the laminated sediments of Lake Van, Turkey. The Holocene 13, 665-675.

Woldring, H., Bottema, S., 2003. The vegetation history of East-Central Anatolia in relation to archaeology: the Eski Acigol pollen evidence compared with the Near Eastern environment. Palaeohistoria 43 (44), 1-34.

Yazicigil, H., Doyuran, V., Camur, M.Z., Duru, U., Sakiyan, J., Yilmaz, K.K., Toprak, F.O., Pusatli, T., 2001. Hydrogeology-Hydrogeochemistry Baseline Study of the Kazan Trona Project Area. Middle East Technical University, Ankara.

Yazicigil, H., Er, C., Ates, J.S., Camur, M.Z., 2009. Effects of solution mining on groundwater quality in the Kazan trona field, Ankara-Turkey: model predictions. Environmental Geology 57, 157-172. 